\title{
Lara Fabian
}

\section{Russian Perspectives on Eurasian Pasts}

\section{Russia and Eurasia}

For the last three centuries, the ancient pathways running across the Eurasian steppe belt have fallen along the southern fringes of the Russian Empire and its proximate successors, the Soviet Union, and now the Russian Federation, as well as a constellation of post-Soviet states. There has been a long and robust research tradition about Eurasia within the Russian academic sphere - the intellectual space anchored in St. Petersburg and Moscow, but extending far beyond. The Russian school of research on ancient Eurasia, as a result of direct and regular contact with the diverse territories of the Black Sea, the western and eastern reaches of the Eurasian steppe, and Central Asia, offers a wide-angle view on historical, social, and economic developments across the sweeping territory (map 1). It is a perspective

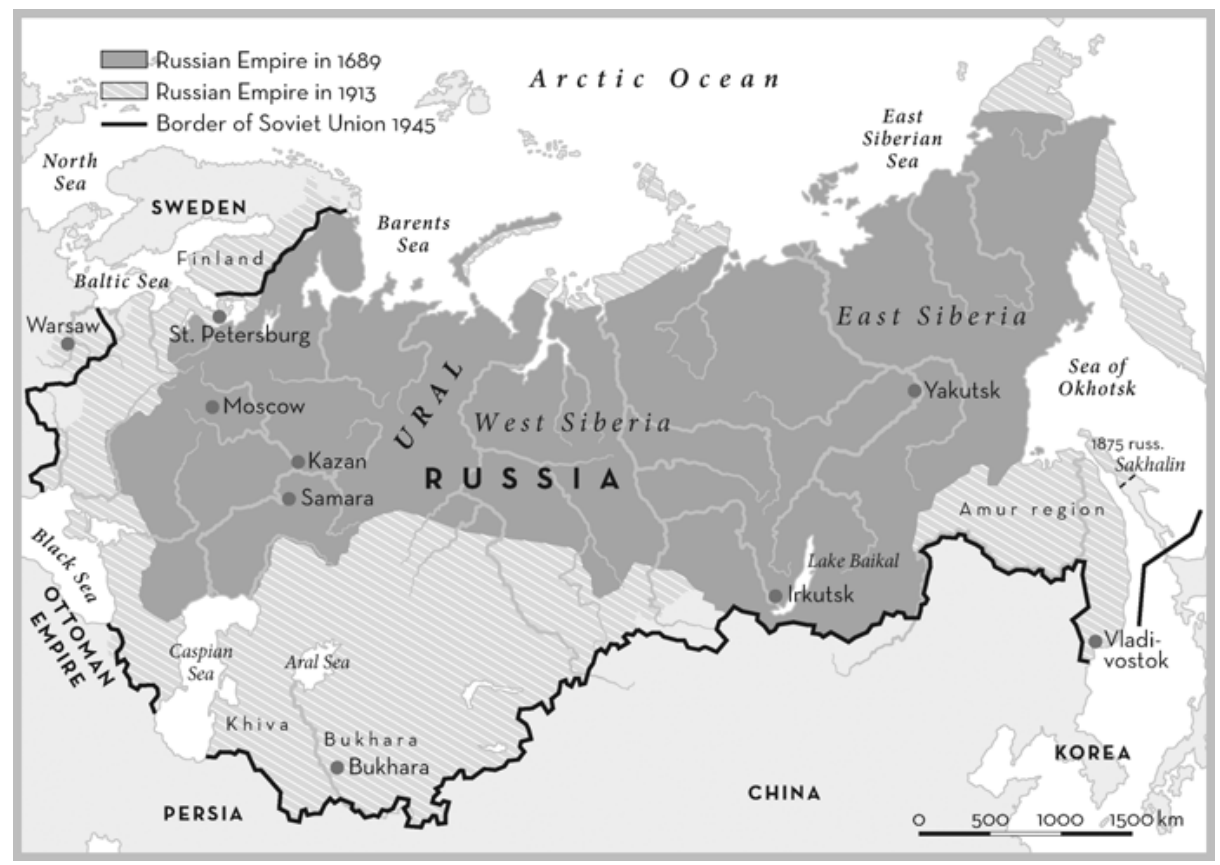

Map 1: Territorial extent of the Russian Empire $(1689,1913)$ and the Soviet Union (1945). (C) Peter Palm.

Note: Thanks to Sergei Krikh and Bruce Grant for their helpful comments on this chapter.

Ә Open Access. (c) 2020 Lara Fabian, published by De Gruyter. (c) BY-NC-ND This work is licensed under the Creative Commons Attribution-NonCommercial-NoDerivatives 4.0 License.

https://doi.org/10.1515/9783110607741-022 
unlike that found in any other 'national' tradition studying the region, shaped by a distinct set of imperial rhythms and social and intellectual currents.

For much of the twentieth century, anglophone work on antiquity treated Russian scholarship on these spaces and their economies as, at best, a footnote: either hopelessly derivative or unforgivably Marxist. ${ }^{1}$ Motivated by both these ideological preconceptions and hampered by issues of accessibility (physical and linguistic), dominant paradigms of historical thought in the anglophone and Western European worlds overlooked research conducted within the Russian framework, generating meaningful gaps in our understandings of ancient Eurasia's connectivities. ${ }^{2}$

\section{I.1 The Prism of Rostovtzeff}

For studies of ancient economic history, however, the works of the historian Michael Ivanovich Rostovtzeff (1870-1952) stand as a visible exception. Rostovtzeff came of age in the Russian Empire. At 47, he emigrated to England and then to the United States in the wake of the Russian Revolution. Along the way and in the midst of considerable personal precarity, he wrote the first of his two seminal studies of the ancient economy, Social and Economic History of the Roman Empire (1926). ${ }^{3}$ Along with his later Social and Economic History of the Hellenistic World (1941), it dominated discourse on the ancient economy in the Western European and Anglo-American spheres for the next half century, while also playing an important role in discussions in the Soviet Union. ${ }^{4}$

Rostovtzeff came by his career naturally: the son of a classicist father who was a teacher and imperial educational administrator. Born in Zhitomir, he spent his early life in Kiev attending the same school where both his father and grandfather had taught. He eventually studied at St. Petersburg University, which remained the center of his academic life until he left Russia. ${ }^{5}$ Maintaining close relationships with German academics in these early years, Rostovtzeff pursued wide-ranging interests. ${ }^{6}$ He published studies on classical antiquity that foreshadowed his Englishlanguage treatises, but also explored other strands of research, ranging from the

\footnotetext{
1 It is easy to overgeneralize, but for a sense of the midcentury polemic, see Miller 1956. Consider, however, Mongait (1955) 1961, and the generally positive review in Glaesser 1957.

2 The later Soviet period saw an increase in interest in Soviet science among foreign scholars. On archaeology, see Klejn 1977; Trigger 1978. On ancient history, see Raskol'nikova 1975.

3 Bongard-Levin 1997 offers the most detailed recontextualization of Rostovtzeff. In English, see Wes 1990 and Bongard-Levin 1999.

4 On Rostovtzeff in Western European scholarship, see von Reden and Speidel, ch. 17, this volume. For Rostovtzeff in Soviet ancient economic discourse, see Krikh 2013b, ch. 3.2.

5 See Wes 1988; Zuev 1997b, 50-54 on Rostovtzeff's early life.

6 Kreucher 2005.
} 
Iranian background of the Scythians to studies of coins from the Black Sea coast. ${ }^{7}$ He left Russia in 1918, apparently intending to return, but he never did. ${ }^{8}$ Following a difficult period in Oxford, Rostovtzeff moved to America, and by 1925 settled in to a prominent post at Yale University. He spent the rest his career there, publishing voluminously throughout the 1920 s and 1930s. His trajectory, then, led from the Kiev of his youth, through the late Russian imperial academia where he matured, and finally to the American universities where he spent his latter years.

For an anglophone audience, Rostovtzeff represents a rare point of contact between the Russian and Western European intellectual traditions in the twentieth century. The scholarship that he offered to his anglophone readers was something new. As the historian and historiographer Momigliano wrote of his first encounter with The Social and Economic History of the Roman World as a university student in the late 1920s:

\begin{abstract}
We were accustomed to books on ancient history where the archaeological evidence, if used at all, was never presented or explained to the reader. Here a lavish series of plates introduced us directly to the archaeological evidence, and the caption of each plate really made us understand what one could learn from apparently insignificant items. ... Learning we knew, but here was overwhelming learning on out-of-the-way subjects. And of course the main novelty was the text itself. ... Rostovtzeff delighted and surprised us by what seemed to us his uncanny gift of calling things ancient to life. He guided us through the streets of Rome, Pompeii, Nîmes, and Trèves and showed us how the ancients had lived. ${ }^{9}$
\end{abstract}

For well over half a century, scholars have tried to understand what accounts for Rostovtzeff's paradigm-shifting work. The question of his Russian 'roots' has played a central role in the discourse from the beginning.

I begin this chapter with mention of Rostovtzeff in order to point out the relevance of Russian intellectual history, even to those who have little interest in Russia as such, but I hesitate on this point. It is parochial to suggest that nonspecialists should be interested in Russian scholarship of antiquity only insofar as it helps to understand a figure who became a 'household name' internationally. The Russian tradition offers a long, vibrant, and varied history of research on the ancient world, much of which is directly relevant to contemporary debates about ancient Eurasian. This justifies serious engagement with Russian intellectual history.

There is a more compelling reason for beginning this chapter with a discussion of Rostovtzeff, which is his reception by later scholars. Upon closer consideration, Rostovtzeff is a prism refracting myriad images of himself and his research according to the preconceptions and interests of those who study him. ${ }^{10}$ Take, for example, two opinions among anglophone scholars of how 'Russian' Rostovtzeff's later schol-

7 Zuev 1997a provides the most complete bibliography. See also Welles 1956; Andreau 1989.

8 Bongard-Levin 1999, 9.

9 Momigliano 1954, 334.

10 On Rostovtzeff as a refractor, see Krikh 2009. 
arly production was. In the eyes of Momigliano, "it would be wrong to assume that [Rostovtzeff] had reached intellectual maturity before leaving Russia," 11 while according to Bowerstock, "Rostovtzeff's intellectual formation was essentially complete by the time he turned thirty." 12 Considering the reception of Rostovtzeff among a wider variety of scholars, including both Soviet-period and contemporary Russians, the images multiply. He is a stark modernizer, or a passionate defender of Russian values, or an opponent of the Bolsheviks; each interpretation shapes the understanding of his scholarship. ${ }^{13}$

Over the last 30 years, studies based on increasingly accessible archival records have fleshed out our understanding of Rostovtzeff's numerous and overlapping social and historical contexts, and provide a fuller and more sound basis for reconstructing his personal biography and legacy. ${ }^{14}$ And yet, rather than leading to a single unified vision of the man, this recent research demonstrates how elusive such a reconstruction is. The example demonstrates the complexities of tracing intellectual history, even at the level of a single individual. The problems multiply exponentially when considering the intellectual history of entire research traditions. And yet, as is the case with Rostovtzeff himself, there is both a value in and a necessity to this project if we hope to understand the shape of contemporary research.

\section{I.2 Scope of Chapter}

Within the Russian context, a number of fields have been involved in the study of ancient Eurasia, although the boundaries and disciplinary structures have changed over time. These include broadly classical studies, ${ }^{15}$ Oriental studies, ${ }^{16}$ Slavic stud-

11 Momigliano 1954, 335.

12 Bowersock 1974, 17.

13 Krikh 2009.

14 Chiefly Bongard-Levin 1997. See also: B. D. Shaw 1992; Emmons 2003; Krikh 2006a; Andreau and Bérélowitch 2008; Alipov 2009; Meyer 2009; Tunkina 2014.

15 The term ancient (classical) studies (antikovedenie) came into use in the nineteenth century, describing the study of ancient classical empires materially, historically, and textually. The term most closely parallels the German Altertumswissenschaft - a sign of the close connections between Russian and German scholarship. For Russian-language overviews of the trajectory of the field, see Tunkina 2002; Frolov 2006. On the twentieth century, see Krikh 2013b; Ladynin 2016. It is through the work of Graham (1961a; 1961b) that the anglophone world became acquainted with the study of classical philology in the Soviet Union. On Graham, see Karpiuk and Kulishova 2015.

16 Russian Oriental studies (vostokovedenie) - often called 'Orientology' by anglophone scholars has been the subject of relatively more research among anglophone scholars, resulting in more synthetic English-language works, e.g., Schimmelpenninck van der Oye 2010; Tolz 2011; Kemper and Conermann 2011; Kemper and Kalinovsky 2015. In Russian, a wealth of new information can be found in the five volumes of Naumkin et al. 1997-2014. 
ies, ${ }^{17}$ and eventually archaeology. ${ }^{18}$ Each has approached historical, cultural, and economic questions through its own disciplinary lens. The body of scholarship generated within these disciplines - the intellectual traditions - are united by a shared academic culture and a shared academic language, but they nevertheless offer multiple of perspectives on the Eurasian past.

Before moving further, we need address two issues of vocabulary. The first is the word 'Eurasia,' which has been used by archaeologists and historians as replacement for the no-longer-accurate term 'Soviet' and the problematic 'post-Soviet': a spatial notion describing the territory stretching from the Mediterranean Sea to the Pacific Ocean. Problematically, however, the term carries marked political overtones within the context of contemporary geopolitics that scholars of antiquity should recognize, even as we continue to use the word. ${ }^{19}$

Furthermore, we must consider why and on what grounds we define the intellectual tradition under discussion as 'Russian': do we mean here research conducted by Russian scholars, as opposed to the many non-Russians who have nevertheless been engaged in scholarly enterprise in the Russian Empire and Soviet Union? Or do we rather mean work carried out within a Russian political context - and if so, how do we fit post-Soviet work into this frame? Or instead, do we more narrowly mean those writing in Russian, excluding other regional practices of history writing that developed along the edges of Russian space, from the Balkans to Central Asia, particularly over the last half century? We might, furthermore, ask on what grounds we divide this research tradition from those of neighboring areas in Central and Western Europe, which share deep roots; or why we foreground it, rather than the variety of Persian, Turkic, and Arabic traditions that grew alongside it.

On the one hand, we run the risk of essentializing this tradition - reinforcing a sense of Russian exceptionalism and downplaying the many ways in which it is a constituent part of other approaches to antiquity. ${ }^{20}$ On the other hand, Russian imperialism and colonialism did create a unique configuration of relationships between imperial scholars and their ancient (and modern) subjects, foregrounding

17 Slavic studies (slavistika, slavianovedenie) became the largest field of study within the Imperial Academy of Sciences, although its relationship to the subject under consideration here is complex. On the history of the field, see Lapteva 2005; 2012.

18 The development of Russian archaeology has been treated most extensively by Klejn (recently 2011; 2014). Klejn 2012 offers an English-language translation, to which I will refer where possible. Klejn is an important figure in archaeological method and particularly theory, and was one of the early voices introducing anglophone audiences to Soviet and Russian archaeology (Klejn 1977; 1993; Bulkin, Klejn, and Lebedev 1982). Biographical and autobiographical works help to put his research into perspective (Klejn 2010; Leach 2015). His is not, however, the only position on archaeological historiography. On nineteenth- and twentieth-century archaeology, see Platonova 2008; 2010, and also Formozov 1995; 2004.

19 Bassin 2008; Glebov 2008; Shnirelman 2009.

20 Khalid 2000, 697. 
historical narratives that are absent in treatments of the same populations by scholars working in other traditions. Furthermore, the Soviet Union shaped twentiethcentury research in unique and dramatic ways.

'Russian' - perhaps, better, russophone - scholarship about antiquity (defined according to any of the possible definitions offered above), therefore, merits contextualized discussion. Research in this framework was written by scholars from a variety of personal backgrounds, in a number of languages. It was generated within a patchwork of disciplines and political contexts. It has never offered a monolithic view of the past, but rather demonstrates the consistent presence of discrepant narratives.

Here I consider the institutional frameworks for studying Eurasia's antiquity, as well as relevant socio-cultural discourses, moving roughly chronologically. I highlight three recurring themes that shaped research on connectivity and economic development, although not all are explicitly economic: (1) approaches to space; (2) perceptions of self and social location; and (3) and models of social and economic structure.

\section{Rise of an Empire, Rise of a Self-Conscious Past}

Russian research on ancient Eurasia grew alongside the creation and expansion of the Russian Empire, with the early stages emerging under Peter the Great (16821725). ${ }^{21}$ We can scarcely talk about a formal school of scholarship on Eurasia in this period. But a scholarly community began to develop in the new capital city of St. Petersburg, from which the scientific and bureaucratic apparatus of the empire looked east and west to understand Russia's position in the world and chart a course forward. ${ }^{22}$

\section{II.1 Pre-Petrine Contexts}

It is, however, a mistake to start the story with Petrine Russia, ignoring the history of cultural interactions that played out in the Rus' heartland of the later Russian Empire long before Peter the Great. On a local level, these relationships brought sedentary agriculturalists and mobile pastoralists into contact, and in a broader sense, created encounters of European and Asian spheres of interest. ${ }^{23}$ This early

21 Shchavelev 1998 discusses early engagements with archaeology.

22 Examples of pragmatic Petrine use of scientific exploration come from the field of cartography, see D. J. B. Shaw 1996; A. V. Postnikov 2014.

23 Scholarship on the early history and cultural affiliations of Rus', and particularly on the relative 'influence' from Scandinavia, Byzantium, and the steppe have raged for generations. For a recent overview in English, see Dvornichenko 2016. A valuable if contested picture on the place of Rus' 
history of Russia, and later popular and scholarly receptions and interpretations of it, has had long-lasting ramifications on Russian imaginations of the past, which in turn informed scholarship.

Pre-Mongol Rus' (between the late ninth and mid-thirteenth centuries) was oriented in a religio-political sense toward Byzantium. This reality framed local traditions about Mediterranean antiquity within Eastern Mediterranean narratives. ${ }^{24} \mathrm{At}$ the same time, the Rus' were engaged in geopolitical entanglements well past the Mediterranean sphere, including the Varangians (Vikings), the Khazar khaganate in the North Caucasus, and other neighboring steppe pastoralists. ${ }^{25}$ The subsequent centuries are traditionally understood as a period of cultural stagnation and isolation for Muscovite Rus', ${ }^{26}$ despite Mongol influence emanating from Central Asia, as a vassal of the Golden Horde (1283-1480). Of course, the situation was more complicated than this negative portrayal suggests. Access to Mongol trade networks provided broad opportunities for the Slavs and brought them into even closer connection with Eurasia's steppe. ${ }^{27}$

Subsequently, in the period of Muscovite independence and the early days of the Russian Tsardom, negotiations with the steppe frontier increased as Muscovy extended its territory through a process of gradual colonization. ${ }^{28}$ Although classical learning of the type familiar from Europe's Christian centers played a limited role in Muscovite Russia, ${ }^{29}$ hagiographic literature and a fragmentary, translated classical textual tradition brought a Christianized vision of antiquity into Russian cultural fabric. A version of Alexander the Great, for example, appeared in both religious and secular contexts in seventeenth-century Russia, ${ }^{30}$ while the official genealogy of Ivan IV (1530-1584) was said to trace its way back to Augustus. ${ }^{31}$ There was the idea, promoted by some seventeenth-century Muscovite elite, that Moscow stood as the 'Third Rome,' the inheritor of the apostate Latin church and the conquered Byzantium. ${ }^{32}$ It was with the key reconfigurations of Peter the Great, however, that self-conscious knowledge about the Graeco-Roman world became central

can be found in Raffensperger 2012. Archaeology has played an important role in these discussions, see Shepard 2016.

24 Franklin 1992; Thomson 1995 discuss understandings and uses of classical antiquity in Kievan Rus'.

25 On Rus' relationships with pastoralists, see Golden 1991.

26 For an introduction to the Mongol period, see Halperin 1985.

27 Schimmelpenninck van der Oye 2011, 19.

28 Sunderland 2004, 17-34.

29 A small number of Slavonic translations of classical texts were produced (Thomson 1995, 312313). Latinity was nevertheless present across the seventeenth century, see Okenfuss 1995; Vorob'ev 1999.

30 V. V. Postnikov 2006.

31 Madariaga 2005, 32-34.

32 See e.g., Poe 2001; Sinitsina 1998. 
to the development of a new age within Russia, and its presentation to internal and external audiences.

\section{II.2 Early Scholarly Infrastructure}

The Petrine era brought shifts both in the rhetorical presentation of Russia and in the scientific infrastructure of the state. ${ }^{33}$ The infrastructural epicenter was the new St. Petersburg Academy of Sciences, which codified 'historical science' as one of the foundational scholarly aims of the new age in Russia. Research here included interdisciplinary scientific-geographic expeditions sent to distant corners, which set paradigms for state-sponsored research - within which the Great Eurasian Steppe featured prominently. ${ }^{34}$ Additionally, there was an aggressive program of manuscript acquisition and translation of ancient texts into Russian, which finally introduced significant works through secular channels. ${ }^{35}$ The Kunstkamera, which opened as Russia's first public museum in 1714, marks another insititional innovation.

The study of classical antiquity along philological, material, and historical lines was central to this phase of research, but both Sinology and Oriental studies also played a role. The Prussian polymath Theophilus (Gottlieb) Siegfried Bayer who was brought to the Imperial Academy of Science exemplifies these interests. First coming as specialist in classical studies, his interests shifted to the east. Over the course of his career, he published prolifically on historical themes ranging from ancient defensive architecture in the Caucasus and Chinese linguistics to the question of the Scythians and the development of Russia. ${ }^{36}$ Much of this early work at the Imperial Academy was conducted by non-Russian scholars, particularly Germans. ${ }^{37}$ The diffusion of their rarified research was limited, and with few students, they left a relatively shallow mark on later scholarship. Nevertheless, the Petrine era created a foundation for historical and cultural research that would only expand.

By the end of the eighteenth century, Greeks and Romans figured prominently in the cultural imagination of elite Russians. ${ }^{38}$ Influential eighteenth-century scholar Mikhail Vasil'evich Lomonosov (1711-1765) framed Russian history in explicitly Roman terms, drawing straightforward equivalencies between Russian and Graeco-

33 On imperial rhetorical allusions to Mediterranean antiquity, see Wes 1992, 33-36.

34 On scientific attention to the steppe, see Sunderland 2004, 36.

35 Frolov 2006, 48.

36 Dubowoj 1985; Lundbaek 1986.

37 The Orientologist Georg-Jacob Kehr is another example (Schimmelpenninck van der Oye 2010, 33-35).

38 The place of Latin in grammar schools, for example, was politicized, see Okenfuss 1995, 198230. On classics in Russian higher education, see Pozdeeva 1962. 
Roman mythical heroes. ${ }^{39}$ Mikhail Ivanovich Popov (1742-ca. 1790), a poet of the era, presented Slavic mythology in a long-running agonistic struggle with Greek and Roman myth, no less grand, but with its own individual (and superior) character. ${ }^{40}$ Even more explicitly, historian Nikolai Mikhailovich Karamzin, author of an epic history of Russia, wrote the following lines in another epic poem:

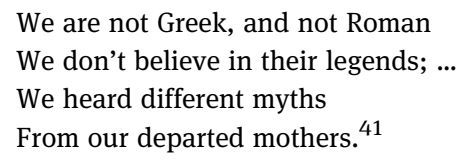

The discourse of Russianness as articulated with respect to both classical and Slavic pasts expanded in the next century, alongside the scientific exploration of these histories.

\section{Russian Expansion and the Nineteenth Century}

In the context of the nineteenth-century Russian Empire, Russian studies of ancient Eurasia developed along axes that were alternately complementary, parallel, and contradictory. In archaeology, large-scale excavations of Greek and Roman sites began on Russian soil, generating vast quantities of new material for study by experts in Russia's imperial cities. In history, there was a growing interest in a different, nonclassical past among Russia's elites: that of the Slavic world. Finally, the field of Oriental studies was formalized within the Russian academy.

Global comparative research shows that reconstructions of the past are shaped by modern imperial and nation-building projects. Historical interest in a given region tends to follow in the footsteps of colonial expansion, which is optimistically credited with 'opening' new spaces to scholarly activity. This general model holds true in the Russian case. From the Black Sea to the Caucasus and Central Asia, Russian scientific research followed the expansion of the empire. ${ }^{42}$ However, one cannot fully understand the nineteenth-century developments in Russia without reference to the debates about the nature of Russian identity that simmered through the century and beyond.

39 Lomonosov argued that "in Russian history, one finds heroes and deeds that are fully comparable to those of the Greeks and the Romans" (trans. Baehr 1978, 3). See also Kahn 1993.

40 Segel 1973, 56. See Lebedev 1992, 62-66 on research into Slavic material culture in this period. 41 From Karamzin's 1795 “Il'ia Muromets.” Quoted, in part, in Lebedev 1992, 62.

42 For an example of the connection between military campaigns and scholarship, see Bayer (1728), which reports on antiquities discovered by an aristocrat accompanying Peter the Great's 1722 campaign against Persia. 


\section{III.1 The Cultural Backdrop: East and West in Russian Politics and Art}

Because the ideas of 'East' and 'West' are so fundamental in scholarly reception of ancient Eurasia, it is worth considering how these issues have played out in the Russian context.

\section{III.1.1 Slavophiles and Westernizers}

Ninteenth-century Russian intellectuals were preoccupied with where to place Russia within the global East-West dichotomy. Was Russia part of the West, part of the East, or something else entirely? The mid-nineteenth-century iteration of this debate - the Slavophile/Westernizer discourse ${ }^{43}$ - had sharp consequences for Russian Oriental and classical studies.

The acephalous and heterodox Slavophile (slavianofil'stvo) and Westernizer (zapadnichestvo) movements pitted elites with a western gaze (the Westernizers) against those who valorized the pre-Petrine past and its putatively pure Slavic roots (the Slavophiles). At stake was the relationship between the pasts and the futures of both Russia and 'the West' - articulated as two distinct cultural spheres. The Slavophiles, inspired by Russia's rich Orthodox heritage and holding to a narrative of Slavic descent, believed it was harmful for Russia to follow Western developmental models. They argued that older collectivist Slavic practices should guide the next stage of Russian progress, rather than imported individualistic paradigms. Westernizers, in contrast, believed that Russia was and had always been European. They blamed what they saw as Russia's cultural stagnation on its fractious medieval history, and especially the Mongol invasions. For them, the path to a stronger Russia lay in the adoption of European intellectual and practical frameworks.

\section{III.1.2 Literary Constructions of Identity and Frontiers}

This Slavophile-Westernizer debate positioned Russia as the meeting point and interpreter between East and West. The imagined locations of the ancient Mediterranean past, the Slavic world, and Eurasian steppe came to play a role in Russian cultural self-perception. The result was a wide range of perspectives about to what extent and in what ways Russia was (or was not) the inheritor of these pasts. Russia's territorial fringes became especially entangled in these discourses.

A clear example of the role of frontiers in the construction of identity - and one explicitly engaging with a variety of heritages - comes from the most famous Rus-

43 See Tolz 2001, 76-94 for an introduction to the terms of debate. 
sian poet, Alexander Pushkin. ${ }^{44}$ In "To Ovid" (K Ovidiiu), Pushkin explores the contrasts between himself and his Roman interlocutor Ovid. The two men, separated by two millennia, each served an exile along the coast of the Black Sea, having antagonized his respective emperor. ${ }^{45}$ Pushkin begins by addressing Ovid and his legacy:

Ovid, I live near the quiet shores To which you once brought your banished native gods And where you left behind your ashes.

Your joyless lament made these lands famous,

Your tender-voiced lyre has not gone mute. ${ }^{46}$

Continuing, Pushkin layers his perception of the zone over Ovid's. Although Ovid characterized the exilic land as a snowy wilderness, ${ }^{47}$ Puskhin found the winter storms entirely normal, and, in fact, rather brief. ${ }^{48}$ Pushkin plays with the inversion of the authorial relationships to the Pontic - south from Pushkin's home, but north from Ovid's. Pushkin is not without sympathy for Ovid, but neither does he entirely identify with him:

As an austere Slav, I have not shed any tears,

But I understand them. A self-willed exile,

Unsatisfied with the world, life, and myself,

I, with a meditative spirit, have now visited

This land, where you once lived out a sad eternity. ${ }^{49}$

In the southern borderlands of the Russian Empire, Pushkin finds a tie to classical antiquity against which he can measure his own experience. The challenges he faced in accommodating his vision of the Black Sea with that of Ovid exemplify the issue facing Russian intellectuals confronting the traces of classical antiquity more broadly. How should they articulate their place with respect to both ancient models and modern contexts?

\section{III.2 Research along the Frontiers}

Frontiers were at the center of Russia's nineteenth-century history. ${ }^{50}$ It has been said that Russian archaeology "formed and grew just as the archaeology of the bor-

44 Formozov 2000 discusses Pushkin's engagements with antiquity. See also Layton 1994 for Russian literary engagements with the frontiers in more depth.

45 For discussions of this poem in English, see Sandler 1989, 41-56; Hokanson 2005.

46 Pushkin, “To Ovid,” 1. 1-5, trans. Sandler 1989, 42.

47 Pushkin, “To Ovid,” 1. 8-10.

48 Pushkin, “To Ovid,” 1. 64-66.

49 Pushkin, “To Ovid,” 1. 54-58, trans. after Sandler 1989, 43. Sandler uses 'severe' instead of 'austere' in 1.54 for Pushkin's surovyi. Pushkin, it should be noted, was not in a self-willed exile. 50 See Bassin 1993 for a comparison of various ways of understanding 'frontiers' in nineteenthcentury thought, in Russia and beyond. 
derlands, the archaeology of the frontier." 51 The same can be said of broader research on Eurasian antiquity. Although the questions asked within each discipline and space differed, there are fundamental points of similarity: nineteenth-century Russian archaeologists, historians, and Orientologists were tasked with studying their own territorial edges, and converting those spaces into Russia.

Each frontier provided scholars the chance to develop new and different connections to Russia's many pasts. These connections, in turn, were reformulated as justifications for Russian expansionary activities. For imperial authorities seeking to control the Black Sea region newly acquired from the Ottoman Empire, for example, the area's deep Christian roots provided a logical entry point that privileged Russian territorial claims. Thus, the vice admiral of the Black Sea Fleet, Aleksei Samuilovich Greig, developed an archaeological project in the newly incorporated Crimean peninsula to memorialize the purported baptismal site of Prince Vladimir, the tenth-century prince who brought Christianity to the Rus' ${ }^{52}$

Later in Central Asia, Russian colonial officials appropriated the figure of Alexander the Great, finding in him a parallel for their conquest of the region and conducting excavations to prove his presence. ${ }^{53}$ At the same time, Russian scholars also cast doubt on just how 'civilized' Alexander's civilizing mission had been and questioned its importance for local historical developments. ${ }^{54}$ In nearly all cases, it was on the frontiers that these questions were negotiated. ${ }^{55}$

\section{Disciplinary Crystallizations}

Within these social currents, the concrete details of Eurasian antiquity came to be studied in ever more organized disciplinary structures. These fields established approaches to Eurasian antiquity that have remained important up to the present.

\section{IV.1 Archaeology and Ancient History}

A significant force in the development of homegrown studies of the ancient past came from archaeological excavations. Although archaeological collections had

51 Smirnov 2011, XX.

52 There, Grieg discovered a fifth- to sixth-century Christian basilica, "unambiguously" demonstrating the Christian past of the area (Smirnov 2011, 211). On the ideological project of this work, see Kozelsky 2004.

53 Russians were not alone in this: the British drew parallels with Alexander the Great in their claims to India. On the limits of this appropriation in the Russian context, see Gorshenina 2017. For a more on the historiography of Central Asia, see Morris, ch. 16, this volume.

54 Gorshenina 2017, 177.

55 Even in the Caucasus - perhaps the most restless of Russia's colonial frontiers - nineteenthcentury writings cast Russia as the protector of an ancient local past, which had been under the shadow of the barbarian overlords (e.g., Kruze 1835, 425). 
been gathered on Russian soil since the Petrine era, extensive archaeological work began only after Catherine II's Russo-Turkish War (1768-1774), which led to the Russian acquisition of coastal territories along the Black Sea. Archaeological interests expanded from the Black Sea coast eastward into new imperial territories, reaching Central Asia and eventually the Caucasus, while also expanding within nonperipheral areas of European Russia and older frontiers like Siberia.

Much of the earliest work was of limited scientific quality from a contemporary point of view, and was indeed little more than treasure-hunting. ${ }^{56}$ Excavations in the Pontic were occasionally under the direction of military commanders, a pattern familiar to other colonial contexts. The Russian academic centers of the period the Academy of Sciences and the State Hermitage Museum - had little involvement with archaeological practice in this period. Interested antiquarians, who created organized and powerful amateur societies, however, conducted methodologically innovative fieldwork. ${ }^{57}$ Regardless of who did the work, the rich Greek and Roman artifacts found along the Black Sea coast fueled new interest in the study of classical antiquity within the academic system and generated an expanding body of publications.

Advances in the study of material culture occurred within a system of increasingly rigorous philological and historical scholarship. Leading figures in the newly reorganized imperial education system, Aleksei Nikolaevich Olenin (1764-1843) and Sergei Semenovich Uvarov (1786-1855), ensured that classics was central among humanities disciplines. ${ }^{58}$ The educational frameworks that emerged were informed by continued close relationships with German scholars, several of whom became foundational figures in Russian universities. ${ }^{59}$

As the archaeological sphere of inquiry spread from the Pontic shores eastward and the study of classics assumed a more formal position in the university system, the role of amateurs diminished. The founding of the Imperial Archaeological Commission in 1859 was a key stage in this process, setting out the goals of Russian archaeology for the first time. ${ }^{60}$ The Commission was the central organizing body for all archaeological investigations in the Russian Empire, and eventually came to

56 Lebedev 1992, 75.

57 These associations held rights to excavate in particular zones, financed their own work, and published their own journals. The best projects took an "ecosystemic" approach, considering local topography and monumental landscapes alongside geological, botanical, historical, ethnographic, and linguistic information (Tunkina 2003, 310).

58 Lebedev 1992, 73-75; Frolov 2015, 140.

59 Frolov 2016.

60 The goals of the Commission were: "1) search for objects from antiquity, predominantly those related to domestic (otchestvennaia) history and the lives of the peoples who lived once in the territory that is today occupied by Russia; 2) the collection of evidence about both the people in the state and the various monuments of antiquity; 3) scientific assessment of the antiquities that are discovered" (Tikhonov 2009, 7). 
be responsible for all permits and archaeological oversight, organized into three sectors: Slavic and Russian archaeology; archaeology of the Orient; and classical and Byzantine archaeology. This was followed by the founding of the Moscow Archaeological Society in 1864. Under the direction of Aleksei Sergeevich Uvarov (1828-1884), this association sponsored All-Russian Archaeological Congresses, which created a unified archaeological knowledge frameworks and an empire-wide system for disseminating the details of archaeological finds. ${ }^{61}$ Over time and against the backdrop of Emperor Nicholas II's (1825-1855) restructuring of the Russian academic system, the Society and its Congresses expanded archaeological work into the imperial provinces. ${ }^{62}$ This period saw methodological and theoretical advances within Russian archaeology broadly, with theories of cultural evolution, diffusion, and change entering the lexicon of Russian practice, although these new currents had less impact in the sphere of 'classical archaeology' in Southern Russia, which remained more traditional in its approaches. ${ }^{63}$

Epigraphic research, which bridged the material and textual worlds, grew in the mid- and late nineteenth century. Fedor Fedorovich Sokolov (1841-1909), an ancient historian at St. Petersburg Imperial University, is credited as the first of the Russian school to turn attention to and inspire interest in epigraphic research. ${ }^{64}$ Issues of socio-economic development also began to occupy a central role in this period: an interest that has been credited to the rapid pace of economic development in late nineteenth-century Russia, and the attendant radical social changes. ${ }^{65}$ Rostovtzeff pursued these subjects in his post-emigration work.

The work of Vasilii Vasil'evich Latyshev (1855-1921), a prominent figure in prerevolutionary classics who published a catalog of inscriptions for the North Black Sea and compiled a sourcebook of Greek and Latin descriptions of the Pontic and Caucasus regions, demonstrates the strength of late imperial scholarship. ${ }^{66}$ Latyshev's biography and training, furthermore, provide a window into the international character of classical studies during this time. ${ }^{67}$ Born in 1855 , he had a classical education at a provincial school, received pedagogical training in St. Petersburg at the Historical and Philological Institute, and was then nominated by the Ministry of Education to travel to Greece and study with Ulrich Köhler and Paul Foucart, the directors of the German Archaeological Institute and French School at Athens, re-

61 Lebedev 1992, 94-105 outlines of A. S. Uvarov's accomplishments.

62 Fifteen Congresses were held from 1869 until 1911, each coinciding with large-scale local excavations, see Komarova 1990.

63 Lebedev 1992, 142. Notably, this extensive work on 'Scythian' monuments (including that on the Kimmerians and the Sarmatians) formed a key part of research in Southern Russia in the late nineteenth century, with far-reaching consequences for ancient history, see Lebedev 1992, 144-146. 64 Frolov 2015, 141-142.

65 Frolov 2006, 312.

66 Latyshev 1890-1906; 1885-1901. See Lebedev 1992, 188-190 for context.

67 Tunkina 1999; Frolov 2006, 218-263. 
spectively. By Latyshev's time, Russian specialists in antiquity had the potential to participate in mainstream European classical scholarship, although much research, nevertheless, remained rooted in Russian networks.

Later opinions on this period were divided - normative Soviet scholarship criticized much of the late imperial work. But others looked back on this era wistfully. In the words of one such scholar, it was a "blooming of the splendid sunset of humanistic culture that marked the last decades in the life of Old Russia." 68

\section{IV.2 Scythian Archaeology and Slavic History}

While the study of classical, particularly Greek, monuments continued to be of importance in the second half of the nineteenth century, there were growing nationalist sentiments and a concomitant interest in the origin of the Slavs. ${ }^{69}$ By the 1850 s, Slavic archaeology itself had acquired a central place within archaeological infrastructure. ${ }^{70}$ One advocate was Aleksei Ivanovich Voitsekhovich, the Ober-procurator of the Holy Synod, who took control of the Russian Archaeological Society in 1850, and advocated for research on Slavic and Orthodox sites. ${ }^{71}$ Scholars developed narratives of the Slavs that placed them as the teleological conclusion of a long line of steppe residents stretching back to the Scythians, and eventually the Sarmatians. ${ }^{72}$

The increasing interest in Slavic history brought new attention to the question of Scythian origins. A growing body of archaeological research on Scythian sites often but not always conducted in the context of work in South Russia mentioned above, and thus as part of 'classical archaeology' - laid the groundwork for these discussions. Excavations of Scythian kurgans were a central focus, with significant work conducted in the lower Dnepr basin and the Taman' Peninsula (e.g., by I. Zabelin). By the end of the nineteenth century, Aleksandr Sergeevich Lappo-Danilevskii (1863-1919) had published on the social organization of Scythian populations. ${ }^{73}$ Periodizations of the various groups and subgroups of archaeological material were well underway at this time, complemented by serious archaeological research that continued throughout the early twentieth century.

In addition to his interests in Graeco-Roman socio-economic history, Rostovtzeff was also a central figure among Scytho-Sarmatian researchers. ${ }^{74}$ He posited an Ira-

\footnotetext{
68 Frolov 2006, 247.

69 Shnirelman 1996, 223.

70 The roots of this lay in the 1820s, when the first imperial archaeological surveys had gone in search of the Eastern Slavs, especially the work of Khodakovskii in Novogorod, see Formozov 1974; Saunders 1982.

71 On research on Orthodox monuments, see Kosykh 2009.

72 Mordvintseva 2013, 205.

73 Lappo-Danielevskii 1887.

74 For two approaches to Rostovtzeff on the Scythians and Sarmatians, see Meyer 2009, and Mordvintseva 2013, 205-207.
} 
nian basis for Scythian style - breaking with many of his nineteenth-century predecessors - and argued that long-distance migrations from the east had brought this material (and these people) to the Black Sea. ${ }^{75}$ Embedded in this theory are two ideas worth consideration: (1) long-distance human migrations as a central vector for cultural transmission; and (2) the steppes of Southern Russia as territory that easily accommodated this type of human movement. ${ }^{76}$ Both of these ideas are echoed in imperial Russian perceptions of medieval history, and particularly in the interaction between Muscovy and the Turko-Mongolian Golden Horde. ${ }^{77}$

\section{IV.3 Oriental Studies}

In tandem with the growth of Slavic history and archaeology, the mid-nineteenth century also saw the expansion of Oriental studies. Universities created faculties for the study of Asian languages in the early nineteenth century. ${ }^{78}$ By midcentury, the central Oriental studies faculty relocated from peripheral Kazan to the seat of imperial power in St. Petersburg. The growth of Oriental studies can be correlated (in some cases directly) with the sentiment that Russia was an ideal mediator between the Near East, Asia, and Western Europe. This was framed in terms of the East-West debates, and also as a natural outgrowth of Russia's geopolitical position. ${ }^{79}$

The department in St. Petersburg had no peers at other European universities, inasmuch as it was a stand-alone faculty devoted only to Oriental studies. ${ }^{80}$ Scholars found themselves in a tug-of-war between factions who saw the department principally as a scholarly enterprise, and those more interested in the pragmatic benefits of preparing Russians for service in the imperial borderlands. ${ }^{81}$ This field had a profoundly practical side: the investigation of non-Russians inside of the Russian territory, particularly those living in "Russia's own Orient." 82

Vasilii Vasil'evich Grigor'ev (1816-1881) was a central figure of midcentury Oriental studies who embodies both of these tendencies. ${ }^{83}$ Grigor'ev, a historian,

75 Rostovtzeff 1922, 11-12.

76 Although with some caution, see Rostovtzeff 1922, 8.

77 Frachetti 2011, 199.

78 Schimmelpenninck van der Oye 2010, 95.

79 The future imperial education minister, S. S. Uvarov wrote: "Russia, lying next to Asia, and mistress of the entire northern part of this continent, shares with the other powers the moral interest that guides their noble enterprises; but she possesses moreover a political interest so clear, so powerful, that a mere glimpse at a map is enough to convince. Russia rests, so to say, on Asia. An arid border of immense dimensions puts her in contact with nearly all of the peoples of the Orient" $(1810,8)$.

80 Schimmelpenninck van der Oye 2010, ch. 8 on the institutional framework.

81 Schimmelpenninck van der Oye 2010, 198.

82 Tolz 2011.

83 On Grigor'ev, see Knight 2000a. 
advocated for the development of a specifically Russian approach to the East in a theoretical, scholarly sense. ${ }^{84}$ But he also harnessed his knowledge about the borderlands in service of the empire, becoming an imperial administrator in the Orenburg region near the modern Russian-Kazakh border. He was not alone in occupying both scholarly and administrative roles; the ties between the scholarly and administrative communities were close throughout the period. At the same time, as recent work on Russian Orientalism has pointed out, the nature of these scholars' engagements with the state (and their perspectives on the non-Russian communities they studied) varied widely, demonstrating the complexity of Orientalist formulations. ${ }^{85}$

Grigor'ev did not accomplish his grand scholarly vision of creating a distinctly Russian approach to Oriental studies, but Baron Viktor Romanovich Rozen (18641908), the most prominent of his students, did. The Rozen School of Oriental studies was rooted in studying the polyfocal cultural interactions that characterize Russia's frontiers, and it presented opposition to the idea of an East-West binary. ${ }^{86}$ Rozen's research fundamentally addressed the question of how to integrate Russia's many ethnic groups into a unified whole. ${ }^{87}$ Despite Rozen's nationalist leanings, ${ }^{88}$ his disciplinary outlook was decidedly Western-facing. Trained partly in Germany, he promoted closer ties between Russian scholars and Oriental studies communities elsewhere in Europe after his ascension to the position of dean of the Faculty of Oriental Studies in St. Petersburg in $1893 .{ }^{89}$

Rozen School academics, like Nikolai Iakovlevich Marr (1864-1934), articulated opposition to the perceived arrogance of European approaches to Oriental studies already in the late imperial period. ${ }^{90}$ Vasilii Vladimirovich Bartol'd (1869-1930) even developed an extended critique of the categorical divides between 'East' and 'West' that underpinned Oriental studies. ${ }^{91}$ Both Marr (a specialist on the Caucasus) and Bartol'd (a historian of Central Asia) went on to become central figures in post-

84 Tolz 2011, 33.

85 There has been a sharp debate over whether Grigor'ev's professional development demonstrates or refutes the existence of an Orientalist gaze à la Said in the Russian context. See Khalid 2000; Knight 2000a; 2000b. For discussions about Russian Orientalism, much of which has unfolded among scholars based in the Anglo-American academic sphere, see especially: Campbell 2002; Etkind 2002: Gerasimov 2002; Knight 2002: Schimmelpenninck van der Oye 2002.

86 On Rozen, see Tolz 2008.

87 As Tolz (2011, 9-10) has pointed out, neither Rozen nor his most prominent disciples were ethnic Russians, and their own personal histories likely shaped their perspectives on both ethnicity and empire.

88 As a proponent of Russian as a scholarly language, for example (Schimmelpenninck van der Oye 2010, 186).

89 This effort began earlier, see Schimmelpenninck van der Oye 2011, 186-189.

90 Tolz 2011, 55. Marr is an extremely important and polarizing figure (both as a linguist and archaeologist). See especially Alpatov 1991; Platonova 1998.

91 Tolz 2011, 50-53. 
revolutionary Oriental studies and archaeology - a context in which their critiques of European scholarly approaches took on new (Marxist) weight.

\section{IV.4 Prerevolutionary Conclusions}

By the First World War and the Russian Revolution, which dramatically reshaped the political context of scholarship, Russian study of the spaces of the ancient Silk Roads had matured along diverse axes. Russian approaches in classical studies were, in general, in keeping with dominant international paradigms, and particularly with those of German academics. Nevertheless, the practical focus of the discipline in Russia produced a subtly different vision of classical antiquity in which the Black Sea played a major role, and in which steppe populations were more visible. Russian Oriental studies, in contrast, charted a path that was self-consciously different from that which was pursued elsewhere in Europe - developing a Russian vision of not just 'the Orient,' but of the concept of 'an Orient' itself. Nevertheless, both classical scholars and late imperial Orientologists felt they were part of a European research community and enjoyed close relationships with their international colleagues. These connections would wither and disappear under the pressures of totalitarianism, with lasting consequences.

\section{Responses to Revolution}

In the years just after the revolution in 1917, rapidly shifting political structures and entirely new pressures from Bolshevik authorities altered disciplinary development. Studies of this period traditionally emphasize ruptures between pre- and postrevolution historical thought. ${ }^{92}$ There is currently, however, a reevaluation of this paradigm from the post-Soviet perspective. This work has brought to the fore many continuities across the chasm of political change and has focused attention instead on the complex processes of adaptation faced by scholars.

Furthermore, it is critical to acknowledge that the postrevolution years were quite simply perilous times for intellectuals. Bolshevik power was harsh, and the first waves of political repression began early, targeting specific individuals as well as perceived elites and intellectuals. Beyond the tremendous personal costs to individuals and their families, this state terror shaped the course of scholarship directly, since the work of disgraced scholars (and of their associates) was deemed subversive and was no longer read or cited. ${ }^{93}$

92 Historiographic work about postrevolution classical studies has been limited, and in the main presents a narrative of decline and intellectual stagnation; see Frolov 2006, 247. Studies on archaeology and Oriental studies have been more abundant and varied. For example, Volkov 2015.

93 On this construction of cause and effect, see Krikh 2016a, 194. 


\section{V.1 Early Developments}

In the wake of the Russian Revolution and the foundation of the Soviet Union, great swaths of the prerevolutionary scholarly infrastructure were dismantled or restructured, often causing disruptions in scholarly activity. In rarer cases, prerevolutionary structures morphed into new Soviet formulations, assuming new titles to emphasize their Marxist underpinnings, but seeing few other initial changes - at least during Lenin's New Economic Policy (1921-1928). Fields viewed as directly relevant to the revolutionary project came more quickly under the aegis of the party. ${ }^{94}$ Scholars meanwhile scrambled in the face of institutional renegotiations to secure their futures amid the turmoil of the period - and some took advantage of new opportunities. Central members of Rozen's Oriental studies school, for example, forged close relationships with Bolshevik authorities, creating a "revolutionary alliance," 95 in which imperial scientific knowledge about Russia's various 'Easts' helped consolidate the new internationalist state. As a result, Oriental studies came to occupy a place of considerable importance within the world of Soviet policy. ${ }^{96}$ At the same time, the participation of Orientologists in this system should not be overstated. There was widespread dislike of the new regime among mainstream metropolitan scholars, even if key figures accommodated themselves to the new political winds. ${ }^{97}$

The situation was different in ancient history. Marx himself was, of course, interested in antiquity; and the classical world played an important role in his philosophical framework. ${ }^{98}$ Nevertheless, although a very specific idea of historical progress lies at the heart of Marxist thought, the formal academic study of classical antiquity was not a priority for the early Soviet state. Ancient historians in general maintained a fairly high degree of autonomy in the 1920s, with many operating on the fringes of Marxist paradigms. This was even true for scholars espousing Marxist positions, like the ancient historian Aleksandr Il'ich Tiumenev (1880-1959), who advocated Marxist history while basing his own writings in the 1920s on non-Marxist historical models developed in Germany around the same period. ${ }^{99}$ Furthermore, although Russian universities continued to teach ancient languages rigorously throughout the Soviet period, there was certainly a minimization of the field, tainted by its roots in the Western European academies and the social circumstances of

\footnotetext{
94 Thus, Oriental studies and ethnography saw a faster course of ideological rearticulation than ancient history and archaeology. On ethnography, see Gadjiev, Kohl, and Magomedov 2007, 122.

95 Hirsch 2005, 21.

96 On the development of Soviet Oriental studies, see Kemper and Conermann 2011; Kemper and Kalinovsky 2015, as well as Battis 2015; Cronin 2015.

97 On the (long) list of Orientologists who were repressed, see Vasil'kov and Sorokina 2003. See also Rodionov 2011.

98 Nippel 2018.

99 Krikh 2013b, 78-79.
} 
prerevolutionary leaders, with their ties to the aristocracy. ${ }^{100}$ Slavic studies suffered similarly due to its close association with the Orthodox church. Work dropped off precipitously and Slavic researchers faced harsh repression. ${ }^{101}$ That discipline, however, resurged in the 1930s and 1940s, and would become a key player in Soviet discussions of ethnogenesis.

Archaeology fell somewhere in the middle. As the discipline of material culture, it found a natural place within the paradigms of Soviet science, given the Marxist interest in articulating a historical materialist presentation of history. Thus, the Russian Academy for the History of Material Culture was quickly founded under the aegis of Lenin in 1919 to move the Imperial Archaeological Commission's work in a new direction. ${ }^{102}$ The discipline, however, had difficulty articulating a clear vision of precisely what this new direction should be. After the turmoil of the immediate postrevolution years, the late 1920s saw robust archaeological research, including the resumption of work at important Black Sea classical sites, and contributions in palaeoethnology. ${ }^{103}$ The 1920 s also witnessed the establishment of archaeological commissions based in the republics of the USSR, expanding the structures of the imperial period and creating an explosion of local ethnographic and archaeological museums. ${ }^{104}$

\section{V.2 The Creation of New Scholarly Norms}

The revolutionary era created new historical questions and changed institutional research frameworks. But during the early 1920s, the Soviet state had not yet developed a clear enough sense of its own priorities to systematize its perspective on the past. ${ }^{105}$ It also lacked an apparatus to uniformly enforce any new ideological bent. After a period of theoretical diversity and experimentation in the 1920s, an increasingly political cadre of postrevolutionary scholars began to create a Soviet Marxist history and history of material culture, eventually with a decidedly Stalinist slant. This perspective was different in scope, structure, and intent from prerevolutionary disciplines. ${ }^{106}$

100 For a view that emphasizes the diminished scale of postrevolutionary classical studies, see Frolov 2015, 144-148.

101 Goriainov 1990; Curta 2001. Byzantine studies were similarly affected, for the same reasons. 102 Soon renamed the State Academy for the History of Material Culture. The most accessible English survey of this period is in Klejn 2012. For a different reading, see Platonova 2010.

103 Platonova 2010, 180-184.

104 Formozov 1995, 31. See, e.g., the establishment of research centers in the Caucasus and Central Asia.

105 Ladynin 2016, 11-12.

106 This was a complicated time with opposing camps of archaeologists and other partisans fighting in Moscow and Petersburg, whom Klejn characterizes as "ideological enthusiasts, at first with little experience of either Marxism or archaeology” $(2012,18)$. On rival scholarly communities, see Metel' 2017. 
The 1930s development of archaeology is best understood as a product of the shifting norms that circulated within Soviet Marxist circles. The Academy for the History of Material Culture's activities were of central importance. The academy was run by N. Ia. Marr and headed by party-affiliated managers (for example, S. N. Bykovskii and F. V. Kiparisov), who advanced a new Marxist model of material culture studies. Their influence eventually spread beyond the Academy, as seen in the case of Vladislav Iosifovich Ravdonikas (1894-1976), who went on to become chair of the archaeology department at Leningrad State University. ${ }^{107}$

This generation found typological studies untenable, saying that the "naked artefactology" that characterized prerevolutionary work was a "product of bourgeois evolutionism, a method which fetishized objects and biologized history." 108 The dominant prerevolutionary interpretive framework, the cultural-historical model, also fell out of official favor at this time, as it was associated with bourgeois formalism. ${ }^{109} \mathrm{~A}$ host of new theories began to circulate, which integrated Marxist perspectives with studies of ancient material. The most influential for our purposes is the model of stadiality, the 'theory of stages,' discussed below. In the following decade, though, Stalin's purges eliminated even some of the most ardent Marxist voices, as numerous members of the Academy of Material Culture were arrested in the mid-1930s. Afterward, the pendulum swung quickly away from theoretical explorations, toward the explication of factual details of the past.

\section{V.3 Post-War Evolutions}

Following the Second World War, and particularly the death of Stalin in 1953, the broader context of humanitarian scholarship changed once again. Oriental studies developed largely under Vasilii Vasilievich Struve's (1889-1965) influence and his research on slavery in the ancient Near East. Struve's work concerned ancient Mesopotamia, but subsequent controversies with Igor' Mikhailovich D'iakonoff (19151999) in the 1950s and 1960s filtered into ancient studies more broadly. ${ }^{110}$ Classical antiquity became the purview of a larger scholarly community who worked, among other places, at reconstituted university departments. Influential participants included representatives of the old guard (S. A. Zhebelev, V. S. Sergeev and N. A. Mashkin), as well as the new (A. V. Mishulin). ${ }^{111}$ In general, research continued to

107 Ravdonikas was not simply a party functionary, but an archaeologist who rose quickly from relative obscurity largely through condemnation of the older generation (especially Gorodtsov). Platonova 2002 provides a nuanced treatment. See also Klejn 2012, 216-232.

108 Klejn 2012, 23.

109 Despite doctrinal protests, both of these models remained central to archaeology in the USSR.

110 On the controversies between Streuve and D'iakonoff, see Krikh 2016b.

111 Ladynin 2016, 16-18. 
center on marginalized groups like the populist masses and slaves, although it lost some of its earlier polemic. ${ }^{112}$ The bottom-up perspective on social life visible in the work of Elena Mikhailovna Shtaerman (1914-1991) represents the late-stage development of Soviet thought on classical society. ${ }^{113}$

The scale of archaeological fieldwork expanded. ${ }^{114}$ Although ideological orthodoxy remained after the 1960s 'thaw,' there was increasing intellectual diversity and methodological and theoretical advancements. ${ }^{115}$ Questions of Slavic prehistory were taken up from a number of positions (e.g., B. A. Rybakov and M. I. Artamonov, advancing the perspectives of autochthony and migration/diffusionism, respectively). Central Asian sites were studied in the framework of the Khorezm expedition (S. P. Tolstov), ${ }^{116}$ as well as by excavations at Nisa (M. E. Masson), and at Panjakent (B. Marshak), among others. In the South Caucasus, relevant research was conducted at necropoleis of Samtavro (A. N. Kalandadze, A. M. Apakidze, and others), and Mingechevir (S. M. Kaziev, P. M. Vaidov, and others), as well in the Armenian highlands (B. B. Piotrovsky). Excavations at Black Sea coastal settlements also continued, as well as work in the North Caucasus. This research produced material-historical syntheses of the polities located along the Eurasian corridors, bringing greater structure to regional understandings. ${ }^{117}$

At the same time, there were persistent divisions in research between the 'center and the periphery' in Soviet scholarship in these years. ${ }^{118}$ 'Periphery' in this sense has both a physical and an institutional valence - including both scholars based outside of the metropolitan centers of Moscow and Leningrad, but also those whose approaches were not normative within these spaces. Soviet-period research was neither a uniform nor linear phenomenon, and understandings and applications of precisely what constituted 'Soviet' thought varied between these research spheres and over time.

112 On slavery and slave revolts, for example, see section VI.2 below.

113 As she says in the introduction to an earlier synthetic work, Moral' i religiia ugnetennykh klassov Rimskoi imperii, "In the Roman Empire, the role of nonmainstream classes was especially great" $(1961,7)$. See Krikh 2013b for a discussion of Shtaerman's approach to ancient history.

114 E.g., Klejn 2012, maps 1-5.

115 Klejn 2012, 38-44, for a survey of this period.

116 Arzhantseva 2013 provides a theoretical perspective on work at Khorezm.

117 E.g., the works of Kamilla Vasil'evna Trever: Trever, Iakubovskii, and Voronetz 1950; Trever 1959.

118 Krikh 2017, on the idea of the 'periphery' and its role. 


\section{Soviet Models of Ancient Societies and Economies}

Recent work on Soviet studies of antiquity makes the point that on balance, the organism of Soviet historical science was not interested in debate. ${ }^{119}$ Instead, it aimed to 'solve' the problems of history. It hoped to reach definitive conclusions about the past through a search for verity (istina) - a sort of platonic truth - and a commitment to orthodoxy. ${ }^{120}$ Once an optimal solution was found, the work of scholars lay not in testing that hypothosis, but rather illustrating it through specific case studies. Additionally, the Soviet Marxist historical approach was not only Marxist in its theoretical leanings, but also in its discursive style and manner of narrative construction. ${ }^{121}$ In this final section of the chapter, I consider three facets of Sovietperiod scholarship that are necessary for understanding Soviet research on the spaces of Eurasia: 1) how the economy was conceived; 2) how social structure and change was modeled; and 3) how personal and collective self-understanding intersected with these social and economic frameworks, particularly in the field of archaeology.

\section{VI.1 The Place of the Economy}

For scholars outside of the Soviet Union, there is a temptation to imagine Soviet scholarship on the ancient economy as Marxist in an uncomplicated way. Such an assumption overestimates the status of economic questions in Soviet thought on antiquity. ${ }^{122}$ On the contrary, as Krikh has recently commented, despite Soviet economocentrism, “... in Soviet science, the economic history of antiquity is transmuted into political history with a slight economic tinge." 123

Understanding this situation requires an appreciation of two discourses. The first pitted Soviet scientists against non-Soviet researchers. In general, Soviet researchers sought to define themselves oppositionally to 'bourgeois history' either for personal ideological reasons, or perhaps more commonly for professional reasons. With respect to the economy, Rostovtzeff was a central target of Soviet scholar-

119 These issues have been explored most directly by Krikh. For an overview in English, see Krikh 2016 .

120 Krikh and Metel' 2014, 7-25.

121 In a related example, Lozny 2017 argues for a distinct discourse of "communist archaeology" (understood differently from Marxist archaeology) that spread throughout the USSR and its sphere of influence.

122 Cf. Marxist scholarship on the ancient economy generated outside of the Soviet Union, see Sullivan 1975; B. D. Shaw and Saller 1981; Morley 1999.

123 Krikh 2013b, 137. 
ly derision, with his research on ancient economies stressing the 'modern' characteristics of the ancient economic landscape. ${ }^{124}$ His position created ample ground for criticism by Soviet contemporaries, who parodied his interpretations as retrojections of capitalism. At the same time, Soviet scholars were interacting with - and even borrowing from - the ideas they encountered in foreign scholarship, including Rostovtzeff's. ${ }^{125}$ It is through this vector that the poles of primitivism and modernism, so critical to twentieth-century debates about the ancient economy in nonSoviet spheres, were also central subjects of debate within midcentury Soviet scholarship. ${ }^{126}$

The second discourse concerned the true and correct interpretation of MarxistLeninist thought on society and the economy, and its relationship to historical scholarship. The Soviet government eventually addressed the question of the "proper' way to write history, demonstrating the centrality of historical narrative-building within governance. ${ }^{127}$ Along the way, a rigid model for understanding historical evolution became doctrinal and precluded investigations into alternative forms of economic evolution. Thus, explicitly economic questions, although putatively central to Soviet Marxist historical understandings, played a marginal role in Soviet research on Eurasian antiquity.

\section{VI.2 Societal Structure and Change}

The influential model of historical evolution with roots in Marx's writings that came to dominate historical thought by the 1930 s is the five-stage system (piatichlenka). ${ }^{128}$ This model posited that all of history was a single process of development through five categorical socio-economic structures: tribal, slave-owning, feudal, capitalist, and, finally, communist. The ascendance of the linear model obviated the need for debates about ancient socio-economic organization. The essential economic questions were, after all, already answered.

The ancient worlds of Greece and Rome occupied a single categorical stage: that of a slave-owning society. As Engels wrote, "Without slavery, no Greek state, no Greek art and science, without slavery, no Roman Empire." ${ }^{129}$ In the field of ancient history, therefore, the issue of slavery as an economic model became a topos. ${ }^{130}$ The

124 Krikh 2013a, 140-186, which insists that it is impossible to trace the paths of the transfer of ideas.

125 E.g., the work of the historian Ranovich, see Krikh 2013b, especially 148-166.

126 Krikh and Metel' 2014, 65-85 discuss one vector for interaction: reviews of foreign literature in major Soviet journals.

127 Yilmaz 2015, 13-15.

128 Loosely adapted from the works of Marx and Engels, debates remain about the roots of the idea. It emerged from the halls of GAIMK over the course of the 1920s (Formozov 2006, 162-163).

129 Engels, Anti-Dühring, part 2, sec. 4 ([1877] 1962, 168).

130 For broad surveys of the subject in scholarship, see Krikh 2013b, 116-132; also Rubinsohn 1987. 
discussion of slave revolts became more lively still after 1933, when Stalin explained the fall of the classical world as the result of "revolutions of slaves that liquidated the class of slave-owners and the slave-owning system as a form of exploitation of the working masses." 131 The problem, of course, was that this assertion did not match the history of slave revolts within the Roman world, which were considerably earlier than the putative transition between the slave-owning means of production of antiquity and the subsequent medieval feudal system.

Finding ways to support Stalin's claim, or at least to accommodate it, became several ancient historians' focus in the 1930s and 1940s. ${ }^{132}$ Even after Stalin's death, there were attempts to widen or reformulate the global slave-revolt hypothesis, considering for example the Social Wars to be a demonstration of a peasant rebellion against their overlords. ${ }^{133}$ Despite considerable effort, however, ancient historians failed to build a durable theoretical apparatus for studying classical antiquity according to the five-stage system, although their rigorous work on slavery is of continuing relevance. ${ }^{134}$

Positioning the ancient Near East within the five-stage development system presented an even larger problem. Dominant understandings in early Soviet years posited that either a feudal or, more particularly, an 'Asiatic mode of production' governed life in the ancient Near East rather than a slave-owning one. ${ }^{135}$ This concept emerges in a shifting and convoluted form from Marx. The term, in essence, describes a system where the state held a monopoly on infrastructural development (and particularly on hydrological management, although alternately on military power), which sustained largely self-sufficient and autonomous local communities. An important commonality in Marx's various presentations of the 'Asiatic mode of production' is the absence of private land ownership, thus inhibiting the development of a land-owning class.

Debates about the 'Asiatic mode of production' raged in the 1920s and early 1930s. The concept had wide-reaching political consequences for Soviet Marxist understandings of the world, and the debates attracted considerable attention at the center of Marxist philosophy and the Soviet leadership. Eventually, the concept was

131 Trans. and references, Tolz 1997, 80. On the broader cultural currents, and the ways in which Stalin's statement fit into (and failed to conform to) historical understandings, see Krikh 2013b, 119; Voloshin and Trandofilov 2015.

132 See especially Korzheva 1976; Krikh 2006b; see also Tolz 1997, 80-81. Sharova 2017 discusses slave revolts in textbooks (which were subject to state scrutiny and therefore offer insight into 'official' thought).

133 Ladynin 2016, 24, discussing the work of Utchenko (1965).

134 Heinen 2010. The work of the American ancient historian, Grace Kazakevich, who moved to the Soviet Union in 1949 after her husband was accused of espionage, deserves mention here. Her works on slavery, while somewhat out of step with later Soviet scholarship, were nevertheless important. See Kazakévich and Kamen 2008; Karpiuk 2016.

135 On the Asiatic mode of production, see Dunn 1982; Fogel 1988. 
determined incompatible with the proper interpretation of Marx, and the subject was stricken from debate for the next several decades, reemerging only in the 1960s. This caused a problem for specialists in the ancient history of the Near East, who had to fit the ancient societies into accepted paradigms of economic evolution. Struve proposed a solution. He reclassed the societies of the Near East as slave-owning on the basis of descriptions of labor patterns in Sumerian texts. ${ }^{136}$ Despite the many infelicities of this argument and controversy around it, it became the cornerstone of mainstream research on the ancient Near East for the next generation.

Struve's refashioning of the Near East into a slave-owning society is but one example of the way that the canonical five-stage model shaped research about antiquity. Beyond ancient history, the five-stage system also shaped archaeological thought. A central question became explaining the cause of changes from one stage to the next. The 'theory of stadial development' mentioned earlier provided a tool to study such structural changes through material culture. Developed on the basis of an idiosyncratic linguistic theory advanced by Marr, ${ }^{137}$ 'stadiality theory' held that all changes in society and culture were actually caused by 'technological innovations,' which is to say the restructuring of economic systems. ${ }^{138}$ As Marr wrote, stadiality theory explained that what appear to be ethnic differences between tribal groups were actually class differences. ${ }^{139}$

Stadial models (at least, as interpreted in the 1930s) ruled out human migrations as a cause of social and linguistic change, and demanded autochthony. ${ }^{140}$ Thus, for example, Rostovtzeff's Scythian and Sarmatian migration hypothesis was firmly rejected as "artificial." 141 At the same time, ethnic arguments that claimed evolutionary connections between the past and the present were viewed for a time as a type of "bourgeois nationalism." 142 In the words of Yilmaz, "Everyone was autochthonous in a spatial sense and at the same time did not bear a single ethnic root."143

\section{VI.3 Ethnicity and Social Location}

The idea of autochthony and perceptions of ethnicity more broadly, however, were in flux during Soviet rule. Over time, it became increasingly acceptable for histori-

136 Krikh 2016a; 2016c.

137 Velmezova 2007 contextualizes Marr's linguistic theory.

138 Klejn 2012, 24; see also Platonova 2010, 253-258. Through the vector of V. Gordon Childe, this idea made its way into global archaeological theory in the 1930s (Trigger 1989, 334-353), and anticipated the theoretical development of New Archaeology (Trigger 1978, 162).

139 Dolukhanov 1995, 124.

140 Slezkine 1996, 843. See e.g., Ravdonikas 1932.

141 Mordvintseva 2013, 208. Although the foremost Scythian scholar in the late 1920s, Boris Grakov, continued to draw on migration theories in his writings (Mordvintseva 2013, 207).

142 Shnirelman 1996, 231.

143 Yilmaz 2015, 9. 
ans and particularly archaeologists to talk about ethnogenesis, which earlier had been suspect. ${ }^{144}$ This discourse, which had percolated for generations, came to the fore over the first decades of Soviet rule. ${ }^{145}$ The concept of 'nationality' was operationalized as 'national consciousness' to develop the new Soviet nationalist identities for all of the citizens of the Soviet Union. ${ }^{146}$

These frameworks took hold quickly in the late 1930s, and applied both to Russian self-perception (generating a resurgence of interest in Slavic history) and to the panorama of national identities of the union-republics. ${ }^{147}$ The effect was a rapid retreat away from Marr's idea of telling history without ethnicity to a version of history entangled much more deeply with ethnic categorization. Eventually, Marr was denounced by Stalin's own pen, ending the supremacy of stadiality, and opening the way for new discussions about both ethnicity and migration as causes of social change. ${ }^{148}$

The roots of the ethnogenetic turn have been traced by some to the situation in the 1940s, when the threat from Germany spurred a "growth of national selfconsciousness, the expression of national pride and the fostering of the best indigenous traditions." 149 This threat was paired with the damage of the war years, which saw tremendous loss of life among young scientists, as within the larger society. ${ }^{150}$ An articulation of Russian heritage free of outside influence, consequently, grew in popularity. ${ }^{151}$ Archaeological explorations were instrumental in this process, tracking the relationships between the Scythians, Sarmatians, and Slavs, and providing the Slavs with unambiguous ancestors in the steppe. ${ }^{152}$ Here, the concept of an 'archaeological culture,' with roots in Russian imperial scholarship, provided the theoretical link between a particular material assemblage, a territorial space, and a historic population.

Eventually, archaeologists working in the various republics also began to incorporate ideas of 'national ethnogenesis' into their works on local populations, bolstered by a rehabilitation of the kraevedenie (local studies) movement. ${ }^{153}$ As ethnogenetic explanations based on archaeological cultures matured, the boundaries

144 Interest in ethnic history lasts into the present day. See Laruelle 2008 for a case study.

145 E.g., Klejn 2012, 135-138.

146 Hirsch 2005.

147 Slezkine 1996, 852.

148 The piece was likely authored by Marr's opponent A. Chikobava (Smith et al. 1998, 178).

149 Bulkin, Klejn, and Lebedev 1982, 276. See the discussion in Kenig, Tikhonov, and Korusenko 2013, 155-159.

150 See Formozov 2006, 76-79.

151 Among these was a new iteration of the long-running Normanist/anti-Normanist controversies on the role of the Vikings in early Russian history, see Melnikova 2013.

152 Shnirelman 1995, 234. Iablonskii 2003; Raevskii 2003 offer a glimpse into the development of discourse of steppe enthnogenesis.

153 Donovan 2015. 
between 'historic tribal populations' and modern nationalities began to dissolve. Given the fractious histories of many of the spaces along the southern Soviet border, the archaeological search for national origins found fertile ground.

At the same time, and somewhat contradictorily, discussions of migration grew in the later years, entering debate after 1960 and assuming a place of prominence, particularly in understanding Eurasia's numerous mobile pastoralist communities. As a result, long-distance migrations have been widely accepted as a normal feature of steppe pastoralism and are used to explain changes in material culture, with varying degrees of nuance.

\section{VI.4 Eurasian Mosaic}

If nineteenth-century Russian archaeology was about frontiers, then twentiethcentury scholarship was, in a certain sense, about borders. Using the administrative system of the USSR to corral data from antiquity, the borders of the Soviet Socialist Republics were used to delineate research territories and became the fundamental unit for data organization for everything from archaeological reports to specialist publications. Within each republic, furthermore, research focused on historical research problems tied to the history of the peoples living within that territory, setting proscribed boundaries both spatially and conceptually. ${ }^{154}$

This scholarship presents a mosaic of images of the past rather than a single totalizing whole. Researchers studying the Eurasian past were under pressure from the central Soviet science structures, and also from the regional research communities in their local republics. Explanatory models for human development - and chiefly the concept of autochthony and that of human migrations - went in and out of vogue in the later years of the Soviet Union. Economic models, meanwhile, downplayed the presence of market economies in these spaces. Although these spaces - from the Black Sea, across the Caucasus, and into Central Asia - were interacting with each other, and with the ancient empires they bordered, the emphasis within archaeological and historical studies in the late twentieth century focused on historically particular, often local, phenomena within each region. It is these overlapping, intertwined, and often conflicting factors that have come together to form the research landscape today.

\section{Contemporary Currents}

Prerevolutionary Russian scholarship established a historical narrative rooted in the wide-open spaces of the imperial frontiers, but stopped short of developing a united

154 Shnirelman 2001, 6. E.g., Alikberov 2015, 24. 
vision of Eurasian antiquity based on this perspective. Soviet research, in contrast, explicity sought to tease out the deeper meaning of ancient history on a global scale, but its focus on a limited number of explanatory paradigms hampered progress. Today, almost thirty years after the end of the Soviet Union, we can only begin to talk about tendencies in post-Soviet ancient Eurasian history. This period began with yet another shift in structure to the practice of science in Russia - one that diminished the position of history, and thus archaeology, vis-à-vis state power. ${ }^{155}$ Today, however, we can speak of robust continuing work in the fields of archaeology and history in the Russian Federation, as well as participation in international scholarly communities. We can also note a particular interest in historiography, which is broadening and deepening our understanding of the various strands of Russian thought about the past.

Scholarship about the space of Eurasia more broadly is increasingly multivocal, but also increasingly fragmented. Much of this work is being generated not within Russia itself, but instead in the former union-republics, now states in their own right. The 1990s were difficult in many of these areas, where border conflicts and widespread economic privation had tremendous consequences for scholars. The academic and scientific infrastructure that existed in these spaces in the Soviet period has not been easy to replace, and funding for research remains a pressing problem.

Nevertheless, each country is in the process of developing its own independent practice of history outside of the Soviet context and an institutional framework to support it. ${ }^{156}$ Some of these traditions still look toward Russia, while others look elsewhere. The publishing landscape is far more diverse, but also atomized. Russian is no longer the primary scholarly language in some areas, as increased publishing in local languages and in English change the picture. Both domestically run archaeological projects and international collaborations have increased, generating considerable new data, and also profoundly divergent interpretations.

\section{References}

Alikberov, А. К. 2015. “Кавказская Албания и лезгинские народы: актуальные проблемы, новые дискурсы” [Caucasian Albania and the Lezgian peoples: Relevant issues and new discourses]. In A. K. Alikberov and M. S. Gadjiev (eds.), Albania Caucasica, 16-27. Москва: Институт востоковедения РАН.

Alipov, Р. А. 2009. “Историк М. И. Ростовцев: научный успех эмигранта” [The historian M. I. Rostovtzeff: The scientific success of the emigrant]. Новый исторический вестник 19.1, 128133.

155 Guliaev and Beliaev 1995 provide a view of institutionally mainstream scholars from after the transition.

156 E.g., Solonari 2003; Laruelle 2010. 
Alpatov, V. М. 1991. История одного мифа: Марр и марризм [The history of one myth: Marr and Marrism]. Москва: Наука.

Andreau, J. 1989. "Bibliographie des oeuvres de Rostovtseff." In M. I. Rostovtseff, Histoire économique et sociale du monde hellénistique, 1273-1303. O. Demange (trans.). Paris: Robert Laffont.

Andreau, J., and W. Bérélowitch, eds. 2008. Michel Ivanovitch Rostovtzeff. Bari: Edipuglia.

Arzhantseva, І. А. 2013. “Имперская археология и археологические империи: советская Хорезмская археологическая экспедиция" [Imperial archeology and archaeological empires: The Soviet Khorezm archaeological expedition]. Этнографическое обозрение, no. 4, 65-87.

Baehr, S. L. 1978. "From history to national myth: Translatio imperii in eighteenth-century Russia." Russian Review 37.1, 1-13.

Bassin, M. 1993. "Turner, Solov'ev, and the 'frontier hypothesis': The nationalist signification of open spaces." Journal of Modern History 65.3, 473-511.

-. 2008. "Eurasianism 'Classical' and 'Neo': The lines of continuity." In T. Mochizuki (ed.), Beyond the empire: Images of Russia in the Eurasian cultural context, 279-294. Sapporo: Slavic Research Center.

Battis, M. 2015. "Soviet Orientalism and nationalism in Central Asia: Aleksandr Semenov's vision of Tajik national identity." Iranian Studies 48.5, 729-745.

Bayer, T. S. 1728. "De muro Caucaseo." Commentarii Academiae Scientiarum Imperialis Petropolitanae, no. 1, 425-464.

Bongard-Levin, G. M. 1999. "M. I. Rostovtzeff in England: A personal experience of West and East.” In G. R. Tsetskhladze (ed.), Ancient Greeks west and east, 1-45. Leiden: Brill.

-, ed. 1997. Скифский роман [The Scythian novel]. Москва: РОССПЭН.

Bowersock, G. W. 1974. "The social and economic history of the Roman Empire by Michael Ivanovitch Rostovtzeff." Daedalus 103.1, 15-23.

Bulkin, V. A., L. S. Klejn, and G. S. Lebedev. 1982. "Attainments and problems of Soviet archaeology." World Archaeology 13.3, 272-295.

Campbell, E. 2002. “К вопросу об ориентализме в России (во второй половине XIX веканачале XX века)" [On the question of Orientalism in Russia (in the second half of the 19th century-early 20th century)]. Ab Imperio, no. 1, 311-322.

Cronin, S. 2015. "Introduction: Edward Said, Russian Orientalism and Soviet Iranology." Iranian Studies 48.5, 647-662.

Curta, F. 2001. "Pots, Slavs and 'imagined communities': Slavic archaeologies and the history of the early Slavs." European Journal of Archaeology 4.3, 367-384.

Dolukhanov, P. M. 1995. "Archaeology in Russia and its impact on archaeological theory." In P. J. Ucko (ed.), Theory in archaeology: A world perspective, 321-336. London: Routledge.

Donovan, V. 2015. “'How well do you know your Krai?' The kraevedenie revival and patriotic politics in late Khrushchev-era Russia." Slavic Review 74.3, 464-483.

Dubowoj, S. M. 1985. "Gottlieb Siegfried Bayer (1694-1738): From Königsberg to the Imperial Academy of Sciences in St. Petersburg." Canadian Slavonic Papers / Revue canadienne des slavistes 27.2, 123-139.

Dunn, S. P. 1982. The fall and rise of the Asiatic mode of production. London: Routledge and Kegan Paul.

Dvornichenko, А. Y. 2016. "The place of the Kievan Rus in history." Вестник СанктПетербургского университета. Серия 2. История, по. 4, 5-17.

Emmons, T. 2003. "The problem of 'Russia and the West' in Russian historiography (with special reference to M. I. Rostovtsev and P. N. Miliukov)." In C. Evtuhov and S. Kotkin (eds.), The cultural gradient: The transmission of ideas in Europe, 1789-1991, 95-108. Lanham, MD: Rowman and Littlefield. 
Engles, F. (1877) 1962. “Anti-Dühring.” In Karl Marx, Friedrich Engels: Werke. Vol. 20, 5-303. Berlin: Dietz.

Etkind, A. 2002. “Бремя бритого человека, или Внутренняя колонизация России” [The shaved man's burden, or the inner colonization of Russia]. Ab Imperio, no. 1, 265-298.

Fogel, J. A. 1988. "The debates over the Asiatic mode of production in Soviet Russia, China, and Japan." American Historical Review 93.1, 56-79.

Formozov, А. А. 1974. “Пушкин и Ходаковский” [Pushkin and Khodakovskii]. Прометей 10, 108-113.

-. 1986. Страницы истории русской археологии [Pages of the history of Russian archaeology]. Москва: Наука.

-. 1995. Русские археологи до и после революции [Russian archaeologists before and after the revolution]. Москва: Институт археологии РАН.

-. 2000. Пушкин и древности. Наблюдения археолога [Pushkin and antiquity: Observations of an archaeologist]. Москва: Языки русской культуры.

-. 2006. Русские археологи в период тоталитаризма: Историографические очерки [Russian archaeologists in the period of totalitarianism: Historiographic essays]. 2nd ed. Москва: Знак.

Frachetti, M. D. 2011. “Migration concepts in Central Eurasian archaeology.” Annual Review of Anthropology 40.1, 195-212.

Franklin, S. 1992. “Greek in Kievan Rus'.” Dumbarton Oaks Papers 46, 69-81.

Frolov, E. D. 2006. Русская наука об античности. Историографические очерки [Russian research on antiquity: Historiographic sketches]. Санкт-Петербург: Издательство СанктПетербургского университета.

-. 2015. “Петербургская историческая школа: традиции классицизма и последствия модернизации” [The Petersburg historical school: Traditions of classicism and the consequences of modernism]. Вестник Санкт-Петербургского университета. Серия 2. История, по. 4, 136-149.

-. 2016. “Academic links between Russia and Germany in the 18th-19th centuries.” Вестник Санкт-Петербургского университета. Серия 2. История, по. 3, 57-67.

Gadjiev, M., P. L. Kohl, and R. G. Magomedov. 2007. "Mythologizing the remote past for political purposes in the North Caucasus.” In B. Grant and L. Yalçın-Heckmann (eds.), Caucasus paradigms: Anthropologies, histories and the making of a world area, 119-142. Berlin: LIT.

Gerasimov, І. 2002. “От редакции: Обновление российской империи и парадоксы ориентализма" [From the editors: Modernization of the Russian Empire and paradoxes of Orientalism]. Ab Imperio, no. 1, 239-248.

Glaesser, G. 1957. “Archaeology in the USSR.” East and West 8.1, 77-99.

Glebov, S. 2008. "Wither Eurasia? History of ideas in an imperial situation.” Ab Imperio, no. 2, 345-376.

Golden, P. B. 1991. "Aspects of the nomadic factor in the economic development of Kievan Rus'." In I. S. Koropeckyj (ed.), Ukrainian economic history: Interpretive essays, 58-101. Cambridge, MA: Harvard University Press.

Goriainov, A. N. 1990. “Славяноведы-жертвы репрессий 1920-1940-х годов. Некоторые неизвестные страницы из истории советской науки” [Slavic studies - victims of the repressions of the 1920s-1940s: Some unknown pages from the history of Soviet science]. Советское славяноведение, по. 2, 78-89.

Gorshenina, S. 2017. "Alexandre le Grand et les Russes: Un regard sur le conquérant porté depuis l'Asie centrale." In C. Antonetti and P. Biagi (eds.), With Alexander in India and Central Asia: Moving east and back to west, 152-193. Oxford: Oxbow.

Graham, H. F. 1961a. "Soviet classical scholarship and the Black Sea region." Classical Journal 56.5, 194-202. 
-. 1961b. "The classics in the Soviet Union." Classical World 54.7, 205-213.

Guliaev, V. I., and L. A. Beliaev. 1995. “О современном состоянии археологии в России (полемические заметки)" [On the current state of archeology in Russia (polemical notes)]. Российская археология, по. 3, 97-105.

Halperin, C. J. 1985. Russia and the Golden Horde: The Mongol impact on Medieval Russian history. Bloomington, IN: Indiana University Press.

Heinen, H. 2010. "Aufstieg und Niedergang der sowjetischen Sklavereiforschung: Eine Studie zur Verbindung von Politik und Wissenschaft." In H. Heinen (ed.), Antike Sklaverei: Rückblick und Ausblick: Neue Beiträge zur Forschungsgeschichte und zur Erschließung der archäologischen Zeugnisse, 95-138. Stuttgart: Franz Steiner.

Hirsch, F. 2005. Empire of nations: Ethnographic knowledge and the making of the Soviet Union. Ithaca, NY: Cornell University Press.

Hokanson, K. 2005. “'Barbarus hic ego sum': Pushkin and Ovid on the Pontic shore.” Pushkin Review 8, 61.

lablonskii, L. T. 2003. “Археология и скифология в этноисторической реконструкции” [Archaeology and Scythology in ethnohistorical reconstruction]. Российская археология, no. 4, 71-79.

Kahn, A. 1993. "Readings of imperial Rome from Lomonosov to Pushkin." Slavic Review 52.4, 745-768.

Karpiuk, S. G. 2016. “Эмили Грейс (Эмилия Львовна Казакевич), американский филологклассик и советский историк" [Emily Grace (Emilia Kazakevich), American philologistclassicist and Soviet historian]. Вестник древней истории 76.1, 141-161.

Karpiuk, S. G., and O. V. Kulishova. 2015. “Хью Грэхем, «индианский эксперимент» и советское антиковедение 50-60-х годов" [Hugh Graham, 'the Indiana experiment' and Soviet ancient studies in the 50's and 60's]. Вестник древней истории, no. 3, 209-217.

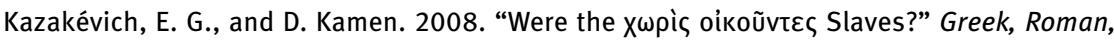
and Byzantine Studies 48.4, 343-380.

Kemper, M., and S. Conermann, eds. 2011. The heritage of Soviet Oriental studies. London: Routledge.

Kemper, M., and A. M. Kalinovsky, eds. 2015. Reassessing Orientalism: Interlocking Orientologies during the Cold War. London: Routledge.

Kenig, A. V., S. S. Tikhonov and M. A. Korusenko. 2013. "The development of ethnoarchaeological thought in Russian archaeology." In A. Marciniak and N. Yalman (eds.), Contesting ethnoarchaeologies: Traditions, theories, prospects, 145-171. New York, NY: Springer.

Khalid, A. 2000. "Russian history and the debate over Orientalism." Kritika 1.4, 691-699.

Klejn, L. S. 1977. "A panorama of theoretical archaeology." Current Anthropology 18.1, 1-42.

-. 1993. "To separate a centaur: On the relationship of archaeology and history in Soviet tradition." Antiquity 67.255, 339-348.

- [Klein]. 2010. Трудно быть Клейном. автобиография в монологах и диалогах [Hard to be Klejn: An autobiography in monologs and dialogues]. Санкт-Петербург: Нестор-История.

- [Klein]. 2011. История археологической мысли. Курс лекций [A history of archaeological thought: Lecture course]. 2 vols. Санкт-Петербург: Петербургского государственного университета.

-. 2012. Soviet archaeology: Trends, schools, and history. K. Windle and R. Ireland (trans.). Oxford: Oxford University Press.

- [Klein]. 2014. История российской археологии: учения, школы и личности [A history of Russian archaeology: Teachings, schools and personalities]. 2 vols. Санкт-Петербург: Евразия.

Knight, N. 2000a. "Grigor'ev in Orenburg, 1851-1862: Russian Orientalism in the service of empire?” Slavic Review 59.1, 74-100. 
-. 2000b. “On Russian Orientalism: A response to Adeeb Khalid.” Kritika 1.4, 701-715.

-. 2002. "Was Russia its own Orient? Reflections on the contributions of Etkind and Schimmelpenninck to the debate on Orientalism." Ab Imperio, no. 1, 299-309.

Komarova, I. І. 1990. “Московское археологическое общество и его роль в развитии местных краеведческих организаций России" [Moscow Archaeological Society and its role in the development of local regional history organizations in Russia]. In Археографический ежегодник 1989, 80-87. Москва: Наука.

Korzheva, K. P. 1976. "Spartacus's rebellion in Soviet historiography." Soviet Studies in History 15.1, 67-97.

Kosykh, V. I. 2009. “Церковно-археологические общества Русской Православной Церкви (конец XIX-начало XX вв.)" [The religious-archaeological societies of the Russian Orthodox Church (end of 19th-beginning of 20th century)]. Ученые записки Забайкальского государственного университета. Серия: Филология, история, востоковедение, по. 3 , 121-126.

Kozelsky, M. 2004. "Ruins into relics: The monument to Saint Vladimir on the excavations of Chersonesos, 1827-57." Russian Review 63.4, 655-672.

Kreucher, G. 2005. Rostovtzeffs Briefwechsel mit deutschsprachigen Altertumswissenschaftlern: Einleitung, Edition und Kommentar. Wiesbaden: Harrassowitz.

Krikh, S. В. 2006а. Упадок древнего мира в творчестве М.И. Ростовцева [The decline of the ancient world in the works of M. I. Rostovtzeff]. Омск: Издательство ОмГУ.

-. 2006b. “«Революция рабов» в советской историографии 30-х годов XX века” ['The Slave revolution' in Soviet historiography during the 30's of the 20th century]. Диалог со временем, по. 17, 224-236.

-. 2009. “МИ Ростовцев: быть в образе и быть образом” [М. I. Rostovtzeff: Being in the similtude and being an image]. Новое литературное обозрение, nо. 95, 146-162.

-. 2013а. “Специфика древней экономики: советская историография в контексте мировой исторической науки" [Specification of the ancient economy: Soviet historiography in the context of global historiographical sciences]. In Древность и Средневековье: вопросы истории и историографии: материалы II Всероссийской научной конференции студентов, аспирантов и молодых учёных (Омск, 25-27 октября 2012 г.), 6-14. Омск: Издательство Омского государственного университета.

-. 2013b. Образ древности в советской историографии [The image of antiquity in Soviet historiography]. Москва: Красанд.

-. 2016a. "Assyriology and Stalinism: Soviet historiography and the invention of slavery in the ancient Near East." Journal of Ancient Near Eastern History 3.2, 191-209.

-. 2016b. “И. М. Дьяконов против В. В. Струве: полемика на полях Шумера” [I. M. D’iakonoff vs V. V. Struve: Polemics in the fields of Sumer]. Вестник древней истории, no. 4, 10111029.

-. 2016с. "В.В. Струве и марризм" [V. V. Struve and Marrism]. In Советский ландшафт древней ойкумены: отечественная наука о древнем Востоке и античности в 1920-1980-е гг. Вестник Университета Дмитрия Пожарского, по. 4, 47-72.

-. 2017. “Феномен периферийности в советской историографии” [The phenomenon of peripherality in Soviet historiography]. Вопросы истории 10, 164-169.

Krikh, S. B., and O. V. Metel'. 2014. Советская историография древности в контексте мировой историографической мысли [Soviet historiography of antiquity in the context of global historiographical thought]. Москва: Ленанд.

Kruze, F. 1835. “О важности южнокавказских областей России в отношении антикварном и о Птолемее, главном писателе в рассуждении географии сей страны” [On the importance of the South Caucasus regions of Russia in relation to antiquity, and on Ptolemy, the most important author in the discourse about the geography of this territory]. Журнал министерства народного просвещения 5.3, 423-439. 
Ladynin, I. А. 2016. “Особенности ландшафта (насколько марксистской была «советская древность»?)" [Features of the landscape (how Marxist was "Soviet antiquity"?)]. Советский ландшафт древней ойкумены: отечественная наука о древнем Востоке и античности в 1920-1980-е гг. Вестник Университета Дмитрия Пожарского 2.4, 9-32.

Lappo-Danielevskii, A. S. 1887. “Скифские древности” [Scythian antiquity]. Записки отделения русской и славянской археологии 4, 352-543.

Lapteva, L. P. 2005. История славяноведения в России в XIX веке [The history of Slavic studies in Russia in the 19th century]. Москва: Индрик.

-. 2012. История славяноведения в России в конце XIX-первой трети XX века [The history of Slavic studies in Russia at the end of the 19th-first third of the 20th century]. Москва: Индрик.

Laruelle, M. 2008. "The concept of ethnogenesis in Central Asia: Political context and institutional mediators (1940-50)." Kritika 9.1, 169-188.

-. 2010. "National narrative, ethnology, and academia in post-Soviet Uzbekistan." Journal of Eurasian Studies 1.2, 102-110.

Latyshev, V. V., ed. 1885-1901. Inscriptiones antiquae orae septentrionalis Ponti Euxini Graecae et Latinae. 4 vols. Санкт-Петербург: Типография Императорской Академии наук.

-. 1890-1906. Известия древних писателей, греческих и латинских, о Скифии и Кавказе [Accounts of ancient Greek and Latin authors about the Scythians and the Caucasus]. 3 vols. Санкт-Петербург: Типография Императорской Академии наук.

Layton, S. 1994. Russian literature and empire: Conquest of the Caucasus from Pushkin to Tolstoy. Cambridge: Cambridge University Press.

Leach, S. 2015. A Russian perspective on theoretical archaeology: The life and work of Leo S. Klejn. Walnut Creek, CA: Left Coast.

Lebedev, G. S. 1992. История отечественной археологии. 1700-1917 гг. [A history of domestic archaeology: 1700-1917]. Санкт-Петербург: Издательство Санкт-Петербургского Университета.

Lozny, L. R. 2017. "Sickle, hammer, and trowel: Theory and practice of archaeology under Communism." In L. R. Lozny (ed.), Archaeology of the Communist era: A political history of archaeology of the 20th century, 9-58. New York, NY: Springer.

Lundbaek, K. 1986. TS Bayer (1694-1738): Pioneer sinologist. London: Curzon.

Madariaga, I. de. 2005. Ivan the Terrible. New Haven, CT: Yale University Press.

Melnikova, E. 2013. “The 'Varangian problem': Science in the grip of ideology and politics.” In R. Taras (ed.), Russia's identity in international relations: Images, perceptions, misperceptions, 42-52. London and New York, NY: Routledge.

Metel', O. V. 2017. “Коммунистическая академия как центр советской исторической мысли (1918-1936 гг.)" [The Communist Academy as the center of Soviet historical thought (19181936)]. In Актуальные проблемы исторических исследований: взгляд молодых ученых: сборник материалов Всероссийской молодежной научной школы-конференции (14-16 сентября 2017 г.). Новосибирск: Институт истории СО РАН.

Meyer, C. 2009. "Rostovtzeff and the classical origins of Eurasianism." Anabases 9, 185-197.

Miller, M. O. 1956. Archaeology in the U. S.S.R. New York, NY: Praeger.

Momigliano, A. 1954. "MI Rostovtzeff." Cambridge Journal 7, 334-346.

Mongait, A. L. (1955) 1961. Archaeology in the USSR. 2nd ed., M. W. Thompson (trans.). Baltimore, MD: Penguin. Originally published as Археология в СССР.

Mordvintseva, V. 2013. "The Sarmatians: The creation of archaeological evidence." Oxford Journal of Archaeology 32.2, 203-219.

Morley, N., ed. 1999. "Marx and antiquity." Special issue, Helios 26.2.

Naumkin, V. V. et al., eds. 1997-2014. Неизвестные страницы отечественного востоковедения [Unknown pages in Russian Oriental studies]. 5 vols. Москва: Восточная литература. 
Nippel, W. 2018. “Marx and antiquity.” In D. Allen, P. Christesen, and P. Millett (eds.), How to do things with history: New approaches to ancient Greece, 185-208. Oxford: Oxford University Press.

Okenfuss, M. J. 1995. The rise and fall of Latin humanism in early-modern Russia: Pagan authors, Ukrainians, and the resiliency of Muscovy. Leiden: Brill.

Platonova, N. І. 1998. “Николай Яковлевич Марр - археолог и организатор археологической науки” [Nikolai lakovlevich Marr - archaeologist and organizer of archaeological research]. Археологические вести 5, 371-382.

-. 2002. “Панорама отечественной археологии на ‘великом переломе’(по страницам книги ВИ Равдоникаса 'За марксистскую историю материальной культуры')” [The panorama of Russian archeology at the 'great turning point' (in the pages of the book by VI Ravdonikas 'Towards a Marxist history of material culture')]. Археологические вести 9, 261-278.

-. 2008. "The phenomenon of pre-Soviet archaeology: Archival studies in the history of Russian archaeology - methods and results." In N. Schlanger and J. Nordbladh (eds.), Archives, ancestors, practices: Archaeology in the light of its history, 47-58. New York: Berghahn.

-. 2010. История археологической мысли в России. Вторая половина XIX - первая треть XX века [A history of archaeological thought in Russia: Second half of the 19th century through first third of the 20th century]. Санкт-Петербург: Нестор-История.

Poe, M. 2001. "Moscow, the Third Rome: The origins and transformations of a "pivotal moment."” Jahrbücher für Geschichte Osteuropas n.s. 49.3, 412-429.

Postnikov, A. V. 2014. История географического изучения и картографирования Сибири и Дальнего Востока в XVII-начале XVIII века в связи с формированием русско-китайской границы [The history of geographical study and mapping of Siberia and the Far East in the 17th-early 18th century in connection with the formation of the Russian-Chinese border]. Москва: Ленанд.

Postnikov, V. V. 2006. “Образ Александра Македонского в русской материальной культуре” [The image of Alexander of Macedon in Russian material culture]. Вестник Дальневосточного отделения Российской академии наук, по. 3, 141-147.

Pozdeeva, I. V. 1962. “Изучение древней истории и древних языков в Московском университете в 50-70-е гг. XVIII в.” [The study of ancient history and ancient languages at Moscow University during the $50 \mathrm{~s}-70$ s of the 18th century]. Вестник древней истории, no. 3, 3-23.

Raevskii, D. S. 2003. “Об историографии скифской проблемы в современном освещении (некоторые замечания к дискуссии)” [On the historiography of the Scythian problem in a modern light (some comments on the discussion)]. Российская археология, по. 2, 64-71.

Raffensperger, C. 2012. Reimagining Europe: Kievan Rus' in the Medieval world. Cambridge, MA: Harvard University Press.

Raskol'nikova, M. 1975. La recherche en Union Soviétique et l'histoire économique et sociale du monde hellénistique et romain. Strasbourg: AECR.

Ravdonikas, V. I. 1932. “Пещерные города Крыма и готская проблема в связи со стадиальным развитием Северного Причерноморья” [Cave cities of Crimea and the Gothic problem in relation to the stadial development of the northern Black Sea region]. Известия ГАИМК $12,5-106$.

Rodionov, M. 2011. “Profiles under pressure: Orientalists in Petrograd/Leningrad, 1918-1956." In Kemper and Conermann (2011), 47-57.

Rostovtzeff, M. I. 1922. Iranians and Greeks in South Russia. Oxford: Clarendon.

-. 1926. The social and economic history of the Roman Empire. 2 vols. Oxford: Clarendon.

-. 1941. The social and economic history of the Hellenistic world. 3 vols. Oxford: Clarendon.

Rubinsohn, W. Z. 1987. Spartacus' uprising and Soviet historical writing. J. G. Griffith (trans.). Oxford: Oxbow. 
Sandler, S. 1989. Distant pleasures: Alexander Pushkin and the writing of exile. Stanford, CA: Stanford University Press.

Saunders, D. B. 1982. "Historians and concepts of nationality in early nineteenth-century Russia." Slavonic and East European Review 60.1, 44-62.

Segel, H. B. 1973. "Classicism and classical antiquity in eighteenth- and early-nineteenth-century Russian literature." In J. G. Garrard (ed.), The eighteenth century in Russia, 48-71. Oxford: Clarendon.

Schimmelpenninck van der Oye, D. 2002. “Ориентализм - Дело Тонкое” [Orientalism - a subtle matter]. Ab Imperio, no. 1, 249-264.

-. 2010. Russian Orientalism: Asia in the Russian mind from Peter the Great to the emigration. New Haven, CT: Yale University Press.

-. 2011. "The imperial roots of Soviet Orientology." In Kemper and Conermann (2011), 29-46.

Sharova, A. V. 2017. “'Революция рабов’ в учебных изданиях ЕA Косминского” [The 'Slave revolution' in the textbook editions of E. A. Kosminsky]. In M. D. Bukharin (ed.), Scripta antiqua. Вопросы древней истории, филологии, искусства и материальной культуры 6 , 421-450.

Shaw, B. D. 1992. "Under Russian eyes." Journal of Roman Studies 82, 216-228.

Shaw, B. D., and R. P. Saller. 1981. "Editors' introduction." In M. I. Finley Economy and society in ancient Greece, ix-xxvi. London: Chatto and Windus.

Shaw, D. J. B. 1996. "Geographical practice and its significance in Peter the Great's Russia." Journal of Historical Geography 22.2, 160-176.

Shchavelev, S. P. 1998. “Становление археологического интереса в России XVII века (ранние находки древностей в районе Курска в отражении приказного делопроизводства)" [Formation of archaeological interest in Russia in the 17th century (early finds of antiquities in the area of Kursk in light of department records)]. Российская археология, nо. 2, 188194.

Shepard, J. 2016. "Back in Old Rus and the USSR: Archaeology, history and politics." English Historical Review 131.549, 384-405.

Shnirelman, V. A. 1995. "From internationalism to nationalism: Forgotten pages of Soviet archaeology in the 1930s and 1940s." In P. L. Kohl and C. Fawcett (eds.), Nationalism, politics and the practice of archaeology, 120-138. Cambridge: Cambridge University Press.

-. 1996. "The faces of nationalist archaeology in Russia." In M. Díaz-Andreu and T. Champion (eds.), Nationalism and archaeology in Europe, 218-242. Boulder, CO: Westview.

-. 2001. The value of the past: Myths, identity and politics in Transcaucasia. Osaka: National Museum of Ethnology.

-. 2009. "To make a bridge: Eurasian discourse in the post-Soviet world." Anthropology of East Europe Review 27.2, 68-85.

Shtaerman, Е. М. 1961. Мораль и религия угнетенных классов Римской империи (Италия и Западные провинции) [Morality and religion of the oppressed classes of the Roman Empire (Italy and the Western provinces)]. Москва: Издательство Академии наук СССР.

Sinitsyna, N. V. 1998. Третий Рим: Истоки и эволюция концепции [Third Rome: The origins and evolution of the concept]. Москва: Индрик.

Slezkine, Y. 1996. "N. Ia. Marr and the national origins of Soviet ethnogenetics." Slavic Review $55.4,826-862$.

Smirnov, A. S. 2011. Власть и организация археологической науки в Российской империи: очерки институциональной истории науки XIX-начала XX века [State power and the organization of archaeological sciences in the Russian Empire: Research on the institutional history of science in the 19th and early 20th century]. Москва: Институт археологии РАН.

Smith, G., V. Law, A. Wilson, A. Bohr and E. Allworth. 1998. Nation-building in the post-Soviet borderlands: The politics of national identities. Cambridge: Cambridge University Press. 
Solonari, v. 2003. “Creating a 'people': A case study in post-Soviet history-writing.” Kritika 4.2, 411-438.

Sullivan, J. P., ed. 1975. "Marxism and the classics." Special issue, Arethusa 8.1.

Sunderland, W. 2004. Taming the wild field: Colonization and empire on the Russian steppe. Ithaca, NY: Cornell University Press.

Thomson, F. J. 1995. "The distorted mediaeval Russian perception of classical antiquity: The causes and consequences." In A. Welkenhuysen, H. Braet, and W. Verbeke (eds.), Mediaeval Antiquity, 303-364. Leuven: Leuven University Press.

Tikhonov, I. L. 2009. “Императорская Археологическая Комиссия: структура и кадровый состав” [Imperial Archaeological Commission: Structure and personnel]. Российская археология, по. 4, 5-17.

Tolz, V. 1997. Russian academicians and the revolution: Combining professionalism and politics. Basingstoke and London: MacMillan Press and St. Martin's Press.

-. 2001. Russia: Reader in Russian history. London and New York, NY: Arnold and Oxford University Press.

-. 2008. "European, national, and (anti-) imperial: The formation of academic Oriental studies in late Tsarist and early Soviet Russia.” Kritika 9.1, 53-81.

-. 2011. Russia's own Orient: The politics of identity and Oriental studies in the late imperial and early Soviet periods. Oxford: Oxford University Press.

Trever, К. V. 1959. Очерки по истории и культуре Кавказской Албании IV в. до н. э.-VII в. н.э. [Studies on the history and culture of Caucasian Albania: 4th century BCE-7th century CE]. Москва: Издательство Академии наук СССР.

Trever, K. V., A. I. lakubovskii and M. E. Voronetz. 1950. История народов Узбекистана [A history of the peoples of Uzbekistan]. Том 1. Ташкент: Издательство АН УзССР.

Trigger, B. G. 1978. “No longer from another planet.” Antiquity 52.206, 193-198.

-. 1989. A history of archaeological thought. Cambridge: Cambridge University Press.

Tunkina, I. V. 1999. “В. В. Латышев: Жизнь и учёные труды (по материалам рукописного наследия)” [V. V. Latyshev: Life and scientific works (on the basis of manuscript evidence)]. In Рукописное наследие русских византинистов в архивах Санкт-Петербурга, 172-288. Санкт-Петербург: Д. Буланин.

-. 2002. Русская наука о классических древностях юга России (XVIII-середина XIXв.) [The Russian science of classical antiquities of southern Russia (18th-mid-19th centuries)]. Санкт-Петербург: Наука.

-. 2003. "The formation of a Russian science of classical antiquities of southern Russia in the 18th and early 19th century.” In P. G. Bilde, J. M. Højte, and V. Stolba (eds.), The cauldron of Ariantas: Studies presented to A. N. Ščeglov on the occasion of his 70th birthday, 303364. Aarhus: Aarhus University Press.

-. 2014. "Rostovtzeff entre archéologies russe et allemande avant 1914." In H. Eristov and F. Monier (eds.), L'héritage germanique dans l'approche du décor antique: Actes de la table ronde organisée à l'Ecole normale supérieure le 23 novembre 2012, 97-114. Bordeaux: Ausonius.

Utchenko, S. L. 1965. Кризис и падение Римской республики [The crisis and fall of the Roman Republic]. Москва: Наука.

Uvarov, S. S. 1810. Études de philologie et de critique. Paris: Didot Frères.

Vasil'kov, I. V., and M. I. Sorokina. 2003. Люди и судьбы. Биобиблиографический словарь востоковедов - жертв политического террора в советский период (1917-1991) [Реople and destinies: Bibliographical dictionary of Orientalists - victims of political terror in the Soviet period (1917-1991)]. Санкт-Петербург: Петербургское востоковедение.

Velmezova, E. 2007. Les lois du sens: La sémantique marriste. Bern: Peter Lang.

Volkov, D. V. 2015. "Rupture or continuity? The organizational set-up of Russian/Soviet Oriental studies before and after 1917." Iranian Studies 48.5, 695-712. 
Voloshin, D. A., and A. A. Trandofilov. 2015. “К вопросу об историографических предпосылках сталинской “теории революции рабов”" [On the question of the historiographic preconditions for the Stalinist 'theory of the revolution of Slaves']. Научно-методический электронный журнал Концепт 30, 541-545.

Vorob’ev, I. К. 1999. Латинский язык в русской культуре XVII-XVIII веков [Latin language in Russian culture of the 17th-18th centuries]. Саранск: Издательство Московского университета.

Welles, C. B. 1956. "Bibliography: M. Rostovtzeff." Historia 5.3, 358-381.

Wes, M. A. 1988. "The Russian background of the young Michael Rostovtzeff." Historia 37.2, 207-221.

-. 1990. Michael Rostovtzeff, historian in exile: Russian roots in an American context. Stuttgart: Franz Steiner.

-. 1992. Classics in Russia 1700-1855: Between two bronze horsemen. Leiden: Brill.

Yilmaz, H. 2015. National identities in Soviet historiography: The rise of nations under Stalin. London: Routledge.

Zuev, V. I. 1997а. “Материалы к биобиблиографии М.И. Ростовцева” [Materials for the bio-bibliography of M. I. Rostovtzeff]. In Bongard-Levin (1997), 200-232.

-. 1997b. “М.И. Ростовцев. Годы в России. Биографическая хроника” [M. I. Rostovtzeff: The years in Russia: Bibliographic chronicle]. In Bongard-Levin (1997), 50-83. 